\title{
Atmospheric outgassing and native-iron formation during carbonaceous sediment-basalt melt interactions
}

John F. Pernet-Fisher ${ }^{1,2^{*}}$, James M.D. Day ${ }^{3}$, Geoffrey H. Howarth ${ }^{1,4}$, Victor. V. Ryabov ${ }^{5}$, Lawrence A. Taylor ${ }^{1}$

Keywords: Native iron; crustal contamination; Permo-Triassic; mass extinction; osmium isotopes; highly siderophile elements; greenhouse gases

\section{Abstract}


Organic carbon-rich sediment assimilation by basaltic magmas leads to enhanced emission of greenhouse gases during continental flood basalt eruptions. A collateral effect of these interactions is the generation of low oxygen fugacities $\left(f \mathrm{O}_{2}\right)$ (below the iron-wüstite [IW] buffer curve) during magmatic crystallization, resulting in the precipitation of native-iron. The occurrence of native-iron bearing terrestrial basaltic rocks are rare, having been identified at three locations: Siberia, West Greenland, and Central Germany. We report the first combined study of Re-Os isotopes, highly siderophile element (HSE: Os, Ir, Ru, Pt, Pd, $\mathrm{Re})$, and trace-element abundances for these three occurrences, in addition to host sediments at West Greenland. To quantify the amount of crustal assimilation experienced by the magmas, we present combined crystallization and assimilation models, together with fractional crystallization models, to assess how relative abundances of the HSE have been modified during crystallization. The radiogenic osmium isotopic compositions $\left(\gamma \mathrm{Os}_{\text {initial }}+15\right.$ to +193 ) of mafic igneous samples are consistent with assimilation of old high Re/Os crustal contaminants with radiogenic ${ }^{187} \mathrm{Os} /{ }^{188} \mathrm{Os}$, whereas the HSE inter-element fractionations $(\mathrm{Pd} / \mathrm{Os} 2$ to $>10,000)$ suggest that some Siberian samples underwent an early stage of sulfide removal.

Metalliferous samples from the Siberian intrusions of Khungtukun and Dzhaltul (associated with the Siberian flood basalts) yield internal ${ }^{187} \mathrm{Re}_{-}{ }^{187}$ Os ages of $266 \pm 83 \mathrm{Ma}$ and $249 \pm 50$ Ma, respectively, reflecting late-Permian emplacement ages. These results imply that crustal assimilation took place prior to crystallization of native-Fe. In contrast, metalliferous samples from Disko Island and Bühl (associated with the West Greenland flood basalts, and the Central European Volcanic Province, respectively) have trends in ${ }^{187} \mathrm{Re} /{ }^{188} \mathrm{Os}-{ }^{187} \mathrm{Os} /{ }^{188} \mathrm{Os}$ space corresponding to apparent ages older than their reported crystallization ages. These anomalous ages probably reflect concurrent assimilation of high Re/Os, radiogenic ${ }^{187} \mathrm{Os}$ crust during crystallization of native-Fe, consistent with the character of local West Greenland sediments. In all three locations, calculations of combined assimilation of crustal sediments and fractional crystallization indicate between 1-7 \% assimilation to account for the Os-isotope systematics. In the case of Siberian samples, incompatible trace-element abundances indicate that lower crustal assimilation may have also occurred, consistent with the suggestion that crustal assimilation took place prior to native-Fe precipitation. The extent of local crustal contamination at Disko Island and Bühl necessitates that significant quantities of $\mathrm{CH}_{4}, \mathrm{CO}, \mathrm{CO}_{2}, \mathrm{SO}_{2}$ and $\mathrm{H}_{2} \mathrm{O}$ were released during assimilation of carbonaceous 
sediments. Consequently, carbonaceous sediment-basalt melt interactions have collateral effects on total gas output from flood basalt volcanism into the atmosphere. However, the amount of carbonaceous sediment contamination experienced by melts forming the Khungtukun and Dzhaltul intrusions alone, cannot explain the major C-isotope excursions at the Permo-Triassic mass-extinction event. Instead, further unsampled intrusions that also experienced significant carbonaceous sediment-melt interactions would be required. Enhanced greenhouse gas-emission during the Permo-Triassic mass extinction may have been facilitated by a combination of mantle melting and carbonaceous sediment-melt interactions, together with other proposed mechanisms, including wildfires, or by microbial metabolic exhalation.

\section{Introduction}

Assimilation of crust by basaltic magmas is a near-ubiquitous process during intraplate volcanism (e.g., Carter et al., 1978; Cox, 1980; Carlson et al., 1981; Day, 2016), making the study of these processes critical for understanding the petrogenetic history of magmas. Occurrences of native-Fe in terrestrial basaltic rocks are rare, due to the generally more oxidizing magmatic conditions of Earth's crust. Magmatic oxygen fugacities $\left(f \mathrm{O}_{2}\right)$ in the crust are typically close to the quartz-fayalite-magnetite [QFM] buffer curve (e.g., Frost, 1991). In order to co-precipitate native-Fe and silicate minerals within terrestrial magmatic systems, $f \mathrm{O}_{2}$ must be lowered at or below the iron-wüstite [IW] buffer curve ( 5 log units below QFM). A primary mechanism to drive magmatic $f \mathrm{O}_{2}$ conditions below the IW buffer curve is by assimilation of highly-reduced C-rich organic material, including carbonaceous shales or hydrocarbon-rich rocks (e.g., coal). Under these reducing conditions, $\mathrm{Fe}$ preferentially forms $\mathrm{Fe}-\mathrm{C}$ metal alloys that have eutectic temperatures similar to typical basaltic magmas $\left(\sim 1200^{\circ} \mathrm{C}\right.$; e.g., Chipman, 1973). Experiments have shown that assimilation of limited organic matter $\left(<0.5\right.$ wt. \%) can decrease the $f \mathrm{O}_{2}$ conditions of a parental magma by several log units (Iacono-Marziano et al., 2012).

To date, native-Fe occurrences have been reported at three locations worldwide: the Permo-Triassic Siberian traps (Khungtukun and Dzhaltul intrusions, Yakutia, Russia); Paleocene West Greenland lavas (Disko Island), and Miocene volcanics from Central Germany (Bühl). All three localities form part of larger volcanic provinces, including the 
voluminous Siberian large igneous province (LIP), the North Atlantic LIP, and the Central European Volcanic Province (Figure 1) respectively. These volcanic provinces are situated within continental crustal terranes with thick sedimentary packages, potentially giving rise to complex crust/magma interactions. Constraining the effects of crustal contamination is necessary in studies investigating mantle sources and processes, due to extensive geochemical modification that can occur to parental magmas during contamination. Here we use rhenium-osmium isotopes and highly siderophile element (HSE: Os, Ir, Ru, Pt, Pd, Re) abundances, coupled with trace element abundances, to assess the role that fractional crystallization and crustal contamination play in modifying the siderophile element and isotope systematics using combined assimilation and fractional crystallization modeling. This form of investigation not only enables quantification of how native-Fe crystallization can act to modify the ${ }^{187} \mathrm{Re}_{-}{ }^{187}$ Os and HSE abundance systematics of magmas traversing through the continental crust, but also allows estimates of crustal assimilation that took place in these settings. Using these crustal assimilation estimates, it is possible to calculate the amount of carbonaceous sediment assimilation that took place during native-Fe formation and to assess the collateral effects of C-rich sediment-basaltic melt interactions, such as the liberation of volatile species, including $\mathrm{H}_{2} \mathrm{O}, \mathrm{CO}, \mathrm{CO}_{2}, \mathrm{CH}_{4}$, or $\mathrm{SO}_{2}$.

\section{Samples and Analytical Methods}

\subsection{Samples}

Samples used in this study represent all textural occurrences of magmatic native-Fe recognized to date on Earth. Oldest occurrences are from the tholeiitic Khungtukun and Dzhaltul intrusions, part of the Permo-Triassic Siberian LIP (250 \pm 2 Ma; Kamo et al., 2003). These mafic intrusions are in an area known for economic deposits of $\mathrm{Cu}-\mathrm{Ni}$-PGE rich sulfides (e.g., Noril'sk, Yakutia; Figure 1a). Both Khungtukun and Dzhaltul are directly underlain by Carboniferous-Permian coal-bearing terrigenous deposits (Ryabov et al., 2014). All samples have a typical basaltic/doleritic silicate mineral assemblage consisting of olivine, clinopyroxene, and plagioclase. Khungtukun samples have variable metal content ranging from high (YHM; >50 vol. \% metal), intermediate (YIM; 25-50 vol. \% metal), to relatively low (YLM; <25 vol. \% metal). Dzhaltul samples, OZ-82, OZ-101, OZ-244, and OZ-601 represent Fe-rich nodules, whereas sample OZ-01-3 is a native-Fe bearing dolerite dike that cuts the Dzhaltul intrusion, containing $~ 25$ to 30 modal \% native-Fe. The remaining silicates 
consistent of $\sim 5$ to 10 modal $\%$ olivine, $\sim 15$ to 20 modal $\%$ plagioclase, and $\sim 40$ to 50 modal $\%$ pyroxene. No chromite grains have been observed within these samples. Sulfides (mostly troilite) are not common $(<0.1$ modal \%), occurring as sparsely disseminated fine-grained (< $\sim 30 \mu \mathrm{m})$ phases. Within the dike (OZ-01-3), graphite is also preserved.

West Greenland native-Fe tholeiitic basalt occurrences (61 \pm 1 Ma, Storey et al., 1998) are associated with the North Atlantic LIP (Figure 1b). Sample AS-80-2B is from the main sequence of extrusive units at Disko (Qeqertarssuaq) Island, whereas, sample HC-80 represents a sub-volcanic intrusive complex (the Hammers Dal Complex). On average, the silicate mineralogy consists of $\sim 10$ to 15 modal \% olivine, $\sim 20$ to 25 modal \% plagioclase, and $\sim 50$ to 60 modal \% pyroxene within the extrusive and sub-volcanic units sampled; no chromite grains have been observed within these samples. Large native-Fe rich (> 50 vol. \%) boulders, which probably weathered out of pockets in the sides of dikes where they accumulated, are present along the Disko Island coastline (Clarke and Pederson, 1976). Sample WGLB was obtained from such a boulder and contains > 90 vol. \% metal; the remaining mineralogy of this sample consists of clinopyroxene and plagioclase. Rare small sulfides $(<\sim 100 \mu \mathrm{m})$ are present enclosed within native-Fe grains in all West Greenland samples investigated here, typically at similar modal abundances as the Siberian samples (< 0.1 modal \%), and samples can also contain several weight percent carbon. Basaltic units at West Greenland are underlain by Cretaceous-Paleogene carbonaceous deltaic sediment and Archean-Proterozoic basement (Clarke and Pederson, 1976). Studied sediment samples from Disko Island include a C-rich shale (AS-80-4), a C-rich sandstone (AS-80-9), and a C-poor sandstone (AS80-2sst). Xenoliths of C-rich plagioclase-spinel (HC80-103) and graphite (DIGX) were also analysed.

The Bühl basalt is an alkali-basalt dike within the upper Rhine Graben region of SW Germany (Figure 1c) Silicate mineralogy consists predominantly of clinopyroxene and plagioclase, with lesser (< 10 modal \%) olivine, with no chromite grains being identified. Native-Fe is present as disseminated globules 20 to $80 \mu \mathrm{m}$ in size ( 30 modal $\%$ ). In some cases, the globules are surrounded by sulfides $(<1$ modal \%). No absolute age has been determined for Bühl, however, based on age estimates from other volcanic fields within southwestern and central Germany (Eifel, Rhön, Urach) volcanism in this region occurred 
between 11 and $26 \mathrm{Ma}$ (Lippolt 1982). Together, these volcanic fields form part of the Central European Volcanic province (CEVP; Wimmernauer, 1974). At present, there is little consensus as to whether the CEVP was the result of an upwelling plume, as suggested for Siberia and West-Greenland (Basu et al., 1995; Saunders et al., 1997). Due to the destruction of the Bühl locality, through mining, only sample (B1706) was available for study.

\subsection{Trace-element abundances}

Trace-element analyses and Fe abundances of whole-rock materials were obtained using a ThermoScientific iCAPq c inductively coupled plasma mass spectrometer (ICP-MS) at the Scripps Isotope Geochemistry Laboratory (SIGL), Scripps Institution of Oceanography, following methods described in Day et al. (2014). Due to the metalliferous nature of samples, it was impossible to achieve a completely homogenous powder due to the potential for metal smearing and loss. $50 \mathrm{mg}$ aliquots of larger crushed material masses (typically $>5$ g) were digested, with grain sizes from $<50 \mu \mathrm{m}$ to $\sim 500 \mu \mathrm{m}$. Two aliquots from each sample were digested and analysed in separate analytical sessions, to assess representativeness. Extended methods, including reproducibility are reported in the Supplementary Online Materials (SOM).

\subsection{Rhenium-Os isotopes and HSE abundances}

Samples powders (1 $\mathrm{g}$ for basalts and cumulates, $100 \mathrm{mg}$ for sediments) were prepared for Re-Os isotope and HSE abundance analyses at the SIGL. Samples were sealed in borosilicate Carius tubes, with a custom multi-element spike $\left({ }^{99} \mathrm{Ru},{ }^{106} \mathrm{Pd},{ }^{185} \mathrm{Re},{ }^{190} \mathrm{Os},{ }^{191} \mathrm{Ir}\right.$, ${ }^{194} \mathrm{Pt}$ ), and $9.5 \mathrm{ml}$ of a reagent mixture containing one part concentrated multiply Teflon distilled (TD) $\mathrm{HCl}$ and two parts concentrated TD $\mathrm{HNO}_{3}$ purged of Os by $\mathrm{H}_{2} \mathrm{O}_{2}$ treatment. Mafic sample powders were digested to a maximum temperature of $240^{\circ} \mathrm{C}$ in an oven for 36 to $96 \mathrm{~h}$. The $\mathrm{C}$-rich sediments were digested to a maximum temperature of $180^{\circ} \mathrm{C}$ for $96 \mathrm{~h}$, to avoid excessive pressure generation and consequent failure within the sealed Carius tubes. Osmium was triply extracted from the resultant digested mixture using $\mathrm{CCl}_{4}$ and then backextracted into $\mathrm{HBr}$ (Cohen \& Waters, 1997), prior to purification by micro-distillation (Birck et al., 1997). Rhenium, Ir, Ru, Pt and Pd were recovered and purified from the residual solutions using standard anion exchange separation techniques, outlined in Day et al. (2016). 
Isotopic compositions of Os were measured in negative-ion mode on a ThermoScientific Triton thermal ionisation mass spectrometer (N-TIMS) instrument. Rhenium, Pd, Pt, Ru, and Ir were measured using a Cetac Aridus II desolvating nebuliser coupled to a ThermoScientific iCAPq c ICP-MS. Offline corrections for Os involved an oxide correction; an iterative fractionation correction using ${ }^{192} \mathrm{Os} /{ }^{188} \mathrm{Os}=3.08271$; a ${ }^{190} \mathrm{Os}$ spike subtraction; and finally, an Os blank subtraction. External precision for ${ }^{187} \mathrm{Os} /{ }^{188} \mathrm{Os}$, determined by repeated measurement of 0.035 to $1.7 \mathrm{ng}$ loads of the UMCP Johnson \& Matthey standard was better than $\pm 0.2 \%(0.11380 \pm 15, n=10,2$ st. dev.). Measured Re, Ir, Pt, Pd and Ru isotopic ratios for sample solutions were corrected for mass fractionation using the deviation of the standard average run on the day over the natural ratio for the element. External reproducibility on HSE analyses using the iCAPq c was better than $0.5 \%$ for $0.1 \mathrm{ppb}$ solutions and $0.3 \%$ for $1 \mathrm{ppb}$ solutions (all reported values are blank corrected). Total procedural blanks $(n=7)$ run with the samples had on average (with quantities in pg) $1.4[\mathrm{Re}], 5.9[\mathrm{Pd}], 4.3[\mathrm{Pt}], 3.7[\mathrm{Ru}], 1.0$ [Ir] and 2.0 [Os]. These blanks represented $<1 \%$ of total HSE for most samples, except for the West Greenland sediments (up to $40 \%$ blank contribution for Os in A80-9) and Ir in OZ 101 (12\% blank contribution) and Os in YLM (up to $20 \%$ blank contribution). Blank contributions are provided for each element in Table S4 of the SOM. Standard reference materials and materials with native-iron in the matrices were run during the same analytical period as for this study in the SIGL, and included basalts, peridotites, and meteoritic materials, reported in Day et al. $(2016 ; 2017)$.

\section{Results}

\subsection{Trace-element abundances}

Absolute trace-element abundances and chondrite or primitive-mantle normalized trace-element profiles are presented in Table S1 and Figure 2. Samples with the lowest modal abundance of metal are characterised by Ni depletions (relative to primitive mantle [PM]; McDonough \& Sun, 1995) and high total lithophile incompatible trace-element abundances (Figure 2). In general, absolute Ni abundances vary greatly from 25 to 14,000 ppm. All samples are characterized by enhanced light rare earth element (LREE) abundances, relative to the middle $\mathrm{REE}\left([\mathrm{La} / \mathrm{Sm}]_{\mathrm{PM}} 1.6\right.$ to 3.3$)$. Siberian samples display relatively restricted $[\mathrm{La} / \mathrm{Sm}]_{\mathrm{PM}}(1.5$ to 2.2$)$, whereas West Greenland basalts and cumulates exhibit variable LREE enrichments $\left([\mathrm{La} / \mathrm{Sm}]_{\mathrm{PM}} 1.1\right.$ to 2.7$)$. Bühl has the most pronounced LREE 
enrichment $\left([\mathrm{La} / \mathrm{Sm}]_{\mathrm{PM}} 3.3\right)$, consistent with the origin of its alkaline-basalt parent melt due to low-degree partial melting. West Greenland sediments have LREE enrichments, with $[\mathrm{La} / \mathrm{Sm}]_{\mathrm{PM}}$ ranging from 3.2 to 4.7. Basalts that display elevated $\mathrm{La} / \mathrm{Sm}$ are also characterized by higher $\mathrm{Th}, \mathrm{Rb}$, and $\mathrm{Ba}$ contents. In general, the sediments display the highest abundances of these elements. Several samples, including the sediments, exhibit negative $\mathrm{Ta}$ and $\mathrm{Nb}$ anomalies, and all samples are characterized by positive $\mathrm{Pb}$ anomalies $(\mathrm{Ce} / \mathrm{Pb}$ ranges from 1.1 to 25.2). Uncontaminated terrestrial tholeiites generally display negative $\mathrm{Pb}$ anomalies (e.g., Larson and Pedersen, 2009). Most samples display negative to no Ti anomalies (0.25 to $1.02[\mathrm{Ti} / \mathrm{Gd}]_{\mathrm{PM}}$ ), apart from samples OZ-101, OZ-244, and AS 80-4, which display positive Ti anomalies $\left(3.39,1.83\right.$, and $2.51[\mathrm{Ti} / \mathrm{Gd}]_{\mathrm{PM}}$, respectively).

\subsection{Highly siderophile element abundances}

Abundances of the HSE (Os, Ir, Ru, Pt, Pd, and Re) are reported in Table 1. A general positive correlation exists between the total HSE abundances and siderophile elements, such as $\mathrm{Ni}, \mathrm{Co}$, and $\mathrm{Fe}$, indicating that the bulk of the HSE occurs within native-Fe phases (Figure 3). The total HSE abundances for the Siberian and West Greenland samples span a range, extending from concentrations similar to average tholeiitic and alkali-basalts, to 'economic-grade' abundances (Siberian sample total HSE abundances $=16.4$ to $17,100 \mathrm{ng} \mathrm{g}^{\text {' }}$ ${ }^{1}$; Disko Island total HSE abundances $=7.9$ to $125,000 \mathrm{ng} \mathrm{g}^{-1}$ ). Bühl displays comparable modal proportions of metal to the Siberian and Disko Island samples, but does not display similar HSE enrichments (8.6 to $10.8 \mathrm{ng} \mathrm{g}^{-1}$ total HSE), and Re and Os abundances that overlap those reported previously for alkali-basalts from SW Germany (Blusztajn and Hegner, 2002; Jung et al., 2005). In general, the HSE abundances for replicate analyses of samples exceed the external precision of measurements, suggesting that the samples investigated here are highly heterogeneous with respect to absolute HSE abundances and experience 'nugget effects' due to the distribution of metal (see Section 4.1).

Siberian samples display strong HSE inter-element fractionations (Figure 4), whereby the PPGE ('Pd-platinum group elements', including Pt and Pd) are typically enriched relative to the IPGE ('Ir-PGE', including Os, Ir and Ru) and Re, resulting in 'arched' profiles with a maximum at $\mathrm{Pd}\left([\mathrm{Pd} / \mathrm{Os}]_{\mathrm{CI}}\right.$ values 47 to 2089 , where $\mathrm{CI}$ equals carbonaceous CI chondrite Ivuna normalization; Horan et al. (2003)). Two samples from the Dzhaltul intrusion (OZ-244 
259

260

261

262

263

264

265

266

267

268

269

270

271

272

273

274

275

276

277

278

279

280

281

282

283

284

285

286

287

288

289

290

and OZ-101) display strong negative Ir anomalies ([Ir/Os $]_{\mathrm{CI}} 0.05$ to 0.20 ), which may reflect the removal of Ir-alloy (or possibly chromite) during accent of the magma. West Greenland samples display flatter HSE chondrite normalized profiles, relative to Siberian samples $\left([\mathrm{Pd} / \mathrm{Os}]_{\mathrm{CI}}\right.$ values 0.5 to 6.2$)$ and display positive Pt anomalies (with the exception of AS802B). In general, the HSE abundances reported in this study are within range of values reported for metal particles from Disko Island by Klöck et al. (1986). In contrast to Siberia, Re abundances are enriched relative to the HSE ([Re/Pt $]_{\mathrm{CI}} 3.7$ to 20) in the West Greenland samples. Despite high Re/Os, the Bühl basalt has similar HSE abundances to alkali basalts from other localities world-wide (Figure 4).

West Greenland sediments display variable chondrite-normalized HSE patterns (Figure 5). All samples display fractionated IPGE inter-element ratios, ranging from strongly fractionated (carbon-rich sandstone AS80-9, $[\mathrm{Ru} / \mathrm{Os}]_{\mathrm{CI}}=28$ to 69 ) to moderately fractionated (graphite xenolith DIGX, $[\mathrm{Ru} / \mathrm{Os}]_{\mathrm{CI}}=3$ ). The carbon-rich sandstone (A80-9) and the carbonrich spinel xenolith (HC80103) have relatively unfractionated PPGE inter-element ratios, whereas the carbon-rich shale (AS80-4), the graphite xenolith (DIGX), and the carbon-poor sandstone (AS80-2S) are characterized by positive $\mathrm{Pd}$ anomalies ([Pd/Pt $]_{\mathrm{CI}} 6.9$ to 12$)$. With respect to average continental-crustal values (Peucker-Ehrenbrink and Jahn, 2001), West Greenland sediments extend to lower absolute abundances, with the exception of one crustal xenolith (DIGX) which has similar absolute HSE abundances to average continental-crustal values (Figure 5).

\subsection{Rhenium-osmium isotopes}

Rhenium-Os isotopic data are reported in Table 1. Measured ${ }^{187} \mathrm{Os} /{ }^{188} \mathrm{Os}$ for Siberian samples range from 0.2090 to $0.5577\left(\gamma \mathrm{Os}_{250 \mathrm{Ma}}+12\right.$ to +98$)$, and ${ }^{187} \mathrm{Re} /{ }^{188} \mathrm{Os}$ ranges from 10.3 to 96 . Samples from the Khungtukun intrusion yield an internal errorchron (MSWD = 37) age of $266 \pm 83 \mathrm{Ma}$, with initial ${ }^{187} \mathrm{Os} /{ }^{188}$ Os of $0.157 \pm 0.047(\gamma \mathrm{Os}=+25)$. The Dzhaltul intrusion yields an internal errorchron age of $249 \pm 50 \mathrm{Ma}(\mathrm{MSWD}=337$; Figure 6), with an initial ${ }^{187} \mathrm{Os} /{ }^{188} \mathrm{Os}$ of $0.156 \pm 0.050(\gamma \mathrm{Os}=+24)$. Measured ${ }^{187} \mathrm{Os} /{ }^{188} \mathrm{Os}$ values for the West Greenland basaltic samples range from 0.1509 to 0.2098 ( $\gamma \mathrm{Os}_{61 \mathrm{Ma}}$ from +14 to +43 ), and ${ }^{187} \mathrm{Re} /{ }^{188} \mathrm{Os}$ values range from 5.6 to 37 . These samples also lie on a positive slope on a $\mathrm{Re}-$ Os isotope plot, but do not yield a geologically meaningful age, with samples lying along an 
291

292

293

294

295

296

297

298

299

300

301

302

303

304

305

306

307

308

309

310

311

312

313

314

315

316

317

318

319

320

321

322

84 Ma reference line and defining a radiogenic initial ${ }^{187} \mathrm{Os} /{ }^{188} \mathrm{Os}$ composition of $0.1431 \pm$ 0.0004. Duplicate digestions were performed for Bühl sample BI706, yielding measured ${ }^{187} \mathrm{Os} /{ }^{188} \mathrm{Os}$ of 0.216 and 0.425 and ${ }^{187} \mathrm{Re} /{ }^{188} \mathrm{Os}$ between 67 and 193 . An eruption age of 16 Ma was assumed, resulting in $\gamma \mathrm{Os}_{16 \mathrm{Ma}}$ values of +55 and +196 , illustrating extreme isotopic heterogeneity within this sample. Sediments from West-Greenland have variable measured ${ }^{187} \mathrm{Os} /{ }^{188} \mathrm{Os}$, from 0.317 to 1.16 . A moderate correlation exists between the measured Osisotope composition and ${ }^{187} \mathrm{Re} /{ }^{188} \mathrm{Os}$, consistent with generally Proterozoic ages for these samples. These relationships cannot be used to define a precise age, and the steep trends probably indicate the presence of Proterozoic/Archean detrital material within the sediments (inset, Figure 6c). The $\gamma \mathrm{Os}$ cited in Table 1 for the sediments $\left(\gamma \mathrm{Os}_{61 \mathrm{Ma}}=+144\right.$ to +790$)$ have been age corrected to $61 \mathrm{Ma}$, for comparison with the related basalts.

\section{Discussion}

\subsection{Effect of phase distribution and 'nuggeting' on trace elements and the HSE}

Many of the iron-bearing igneous samples in this study show evidence for elemental and isotopic heterogeneity at the hand-specimen scale. This is reflected in variations in traceelement abundances, HSE abundances and, in some cases, ${ }^{187} \mathrm{Os} /{ }^{188} \mathrm{Os}$ (e.g., Bühl), which can greatly exceed the external analytical precision of the measurements, based on replicate analyses of standards (e.g., Day et al., 2016). As noted previously, the iron-bearing igneous samples show evidence for significant heterogeneity in phase distribution, particularly in the modal abundance of metal relative to silicate or sulfide phases. For example, cumulate samples from the Khungtukun intrusion display a range in metal abundance from $<25$ modal $\%$ to $>50$ modal $\%$. Critically, this means that comparison of data from different aliquots of the rock can potentially generate significant scatter in diagrams. This enables isochrons to be plotted for individual samples (WGLB), taking maximum advantage of phase heterogeneity. However, this may be a concern for major element abundances (e.g., nearly $20 \%$ variation in $\mathrm{Ni}$ in YIM - 10,000-12,000 ppm; Supplementary Information) and comparison of absolute abundances of elements. Nonetheless, while absolute abundances of the incompatible trace elements and HSE may vary, the relative abundances within samples are evidently less variable (e.g., Figures 2 and 4). For these reasons, throughout the rest of the discussion, we emphasise relative abundances of elements, as ratios, rather than focus on absolute abundances. 


\subsection{Fractional crystallization controls on HSE abundances}

It is generally accepted that inter-element HSE fractionations (specially PPGE/IPGE ratios greater than 1) are the result of fractional crystallization (e.g., Crocket and MacRae, 1986). These effects have been demonstrated previously for continental intraplate lavas (Puchtel and Humayun, 2001; Li et al., 2012; Day et al., 2013). Fractionation of PPGE/IPGE ratios are due to differences in the bulk compatibility of these geochemically distinct groupings of elements due to phase removal or addition of minerals such as olivine, chromite, sulfide and platinum-group alloys. Typically, moderately evolved basalts ( $\sim 8$ to 4 wt. \% $\mathrm{MgO}$ ) can display large PPGE/IPGE fractionations (63 to 211 [Pd/Os $]_{\mathrm{CI}}$, Parana Basalts; Rocha-Junior et al., 2012; 1 to 825 [Pd/Os $]_{\mathrm{CI}}$, Coppermine Continental Flood Basalts; Day et al., 2013; 76 to 466 [Pd/Os $]_{\mathrm{CI}}$, Lesser Antilles; Woodland et al., 2002; 22 to $5700[\mathrm{Pd} / \mathrm{Os}]_{\mathrm{CI}}$ Tonga Arc, Dale et al., 2012), whereas primitive basalts, such as picrites display much flatter profiles (0.4 to $7[\mathrm{Pd} / \mathrm{Os}]_{\mathrm{Cl}}$; Ireland et al. 2009). Disko Island and Bühl samples have relatively flat $\mathrm{HSE}$ patterns $\left(0.5\right.$ to $\left.6.2[\mathrm{Pd} / \mathrm{Os}]_{\mathrm{CI}}\right)$, consistent with the primitive nature of their respective tholeiitic and alkali-basalt parental melts (Figure 4; Lightfoot and Hawkesworth, 1997). By contrast, Siberian samples display more fractionated HSE compositions (47 to $\left.2089[\mathrm{Pd} / \mathrm{Os}]_{\mathrm{CI}}\right)$, consistent with significant degrees of crystal-liquid fractionation of the basaltic parental melts that formed these intrusions (Ryabov et al., 2014).

2

To examine if available experimental mineral/melt partitioning data can reproduce the HSE patterns observed in samples (specifically PPGE/IPGE fractionation), and to assess the role that siderophile-element rich phases (such as native-Fe or sulfides) play in fractionating HSE profiles, we used a crystallization model that assumes perfect fractional (Rayleigh) crystallization. As a parental melt, we use an average picrite composition reported for West Greenland (Woodland, 2000) and use bulk D values to calculate crystallization trajectories for geologically reasonable mafic (olivine, pyroxene, and plagioclase) systems. A table summarizing the parameters used for this model is provided in the SOM. To assess the role that native-Fe removal plays in fractionating HSE patterns, we used a sulfide-free picrite bulk D values from Ireland et al. (2009), incorporating variable low proportions (< 1 modal \%) of native-Fe (using the $\mathrm{D}_{\text {metal/melt }}$ parametrizations of Righter et al. (2015) at an $f \mathrm{O}_{2}$ of -1 IW). Regardless of the proportion of native-Fe removed, these models resulted in strong $\mathrm{Pt}$ 
depletions relative to the IPGEs due to the high partition coefficients of Pt relative to Ir and Os. This feature is common to other reported $\mathrm{D}_{\text {metal/melt }}$ values within the literature (e.g., Fonseca et al. 2009; Borisov and Palme, 2000). We also modelled crystallization trends using bulk D values from Mungall and Brenan (2014) for a mafic sulfide bearing $(<0.1$ modal \%) assemblage, to examine whether early sulfide partitioning may be responsible for HSE inter-element fractionations. Mungall and Brenan (2014) do not report bulk D values for Os and Re, so for the modelling, we use values from Brenan (2008) assuming that $\mathrm{D}_{\mathrm{Os}} \approx \mathrm{D}_{\text {Ir }}$ and $\mathrm{D}_{\mathrm{Re}}<\mathrm{D}_{\mathrm{Pd}}$. Overall, assumption of sulfide-loss can reproduce the observed PPGE/IPGE fractionations (Figure 7). The range of $[\mathrm{Pd} / \mathrm{Os}]_{\mathrm{CI}}$ observed in the Siberian samples (47 to 2089 ) is consistent with between $10 \%$ to $40 \%$ total fractional crystallization (models predict 20 to $4515[\mathrm{Pd} / \mathrm{Os}]_{\mathrm{CI}}$ for $10 \%$ and $40 \%$ fractionation respectively), and the range $[\mathrm{Pd} / \mathrm{Os}]_{\mathrm{CI}}$ observed in the Disko Island samples (0.5 to 6.2) is consistent with $<5 \%$ fractional crystallization of the mineral assemblage (Figure 7).

Modelling results are inconsistent with native-Fe crystallization controlling the PPGE/IPGE fractionations. Rather, an early stage of sulfide fractionation may have occurred to fractionate the PPGE from the IPGE in the residual liquid, particularly for the more evolved Siberian samples. Our results are also consistent with HSE ore formation models for Siberia suggesting that some magmas underwent early sulfide removal within deep crustal magma staging-chambers prior to the melt interacting with upper crustal lithologies and surface emplacement (e.g., Li et al., 2009).

\subsection{Crustal assimilation prior to and during native-Fe crystallization}

Most HSE ore formation models that call for early sulfide removal require later crustal assimilation (e.g., Noril'sk, Siberia; Li et al., 2009). Furthermore, carbonaceous sediment-melt interaction is required to precipitate native-Fe. To quantify the extent of magma/crustal interaction, assimilation and fractional crystallization (AFC) was modelled (Figure 8) assuming a parental melt with both a picritic composition (appropriate for tholeiitic basalts, such as those forming the West Greenland and Siberian native-Fe bearing occurrences) and an alkali-basalt composition (appropriate for the small-degree, alkali melts from Central Germany), but with variable initial Os abundances ( $1 \mathrm{ng} \mathrm{g}^{-1}$ and $\left.0.1 \mathrm{ng} \mathrm{g}^{-1}\right)$, assimilating an average crustal composition (e.g., Peucker-Ehrinbrink and Jahn, 2001). It has 
387

previously been shown that variable Os abundances are likely in CFB parental magmas, because of partial melting and source composition (Day, 2013). We did not use a MELTS algorithm because of the reported difficulty of this modelling program in reproducing low $f \mathrm{O}_{2}$ conditions for planetary basalts (e.g., Monders et al., 2007). Within typical mafic systems the $r$ value (rate of assimilation/rate of crystallization) is typically estimated to range from 0.2 to 0.6 (e.g., Blusztajn and Henger 2002). However, Ulff-Møller (1990) has argued that an $r$ value $>1$ may be appropriate for native-Fe forming systems, reasoning that the assimilation of organic compounds may have produced sufficient heat to suppress crystallization. Whereas there is direct evidence of organic material (graphite) in some of the samples investigated here, the textures observed in the Siberian samples indicate that co-crystallization of native$\mathrm{Fe}$ and silicate minerals occurred. Textural evidence therefore suggests that crystallization was not fully suppressed. For this reason, we use an $r$ value of 0.8 for the AFC modelling, noting that a range of values are possible.

Models assuming assimilation of average global crustal compositions (e.g., PeuckerEhrinbrink and Jahn, 2001) yield similar trajectories to the assimilation of crustal compositions that we report for Disko Island (Figure 8). Under conditions of upper crustal composition, Disko Island samples can be accounted for by 1 to $7 \%$ AFC. No one sedimentary unit analysed from West-Greenland can provide a unique solution to encompass the chemical variations observed. This indicates that a heterogeneous mixture of sediments yielding local 'average' compositions represents a reasonable estimate for modelling AFC. A range of potential crustal assimilants has also been reported by Larsen and Pedersen (2009) for basalts from Eastern Greenland. Using the same calculations as used for Disko Island samples ( $r$ values, starting composition etc.), Siberian samples require 2 to $5 \%$ AFC of crustal materials (Figure 8), while the Bühl sample can be accounted for by a similar extent of crustal contamination as the tholeiitic samples ( $7 \%$ AFC). All three native iron bearing mafic igneous localities therefore yield a restricted range in feasible assimilation of carbonaceous sediment and crust of 1 to $7 \%$.

(1)

In addition to the amount of crustal assimilation, the relative timing of assimilation can be inferred from ${ }^{187} \mathrm{Re} /{ }^{188} \mathrm{Os}_{-}{ }^{187} \mathrm{Os} /{ }^{188}$ Os systematics of samples (Figure 6). For example, if crustal assimilation of organic rich sediments occurred prior to the crystallization of native- 
$419 \mathrm{Fe}$, such samples will define isochrons (or errorchrons) with elevated initial ${ }^{187} \mathrm{Os} /{ }^{188} \mathrm{Os}$, due to crystallization from a relatively homogeneous, contaminated basaltic liquid. This appears to be the case for the Siberian Khungtukun and Dzhaltul intrusions. Iron-bearing mafic rocks from these intrusions lie along regression lines that yield ages consistent with the emplacement ages of the Siberian flood basalts and their associated intrusions. These intrusions also have strikingly similar initial ${ }^{187} \mathrm{Os} /{ }^{188} \mathrm{Os}\left(\gamma \mathrm{Os}_{250 \mathrm{Ma}}=+24\right.$ to +25$)$ that are too radiogenic to have been inherited from any known peridotite mantle-source composition (e.g., typically $\gamma \mathrm{Os}_{\text {initial }}<2$; Day, 2013). Figure 8 illustrates that 1 to $7 \%$ crustal contamination of a magma with a starting ${ }^{187} \mathrm{Os} /{ }^{188} \mathrm{Os}$ composition of 0.127 can account for the initial ${ }^{187} \mathrm{Os} /{ }^{188} \mathrm{Os}$ calculated for both intrusions. Combined with the fractionated HSE patterns of mafic rocks from Khungtukun and Dzhaltul, these results imply relatively restricted assimilation combined with significant fractional crystallization and sulfide-loss prior to Fe-metal formation.

Crustal assimilation during crystallization of Fe-bearing basaltic melts is expected to lead to a more heterogeneous Os isotopic composition in resultant mafic rocks, or to mixinglines between the mafic melts and the crustal contaminant in ${ }^{187} \mathrm{Re} /{ }^{188} \mathrm{Os}_{-}{ }^{187} \mathrm{Os} /{ }^{188} \mathrm{Os}$ space. In this scenario, early fractionation of metal phases would lead to depletion of the HSE in the residual basaltic melt. Consequently, later-forming basaltic phases can inherit different Osisotopic compositions if the fractionated melts experiences contamination by radiogenic ${ }^{187} \mathrm{Os} /{ }^{188}$ Os crust. An example of this process is preserved in Disko Island samples, where splits of the Fe-metal cumulate rock WGBL define a regression line yielding an apparent age ( $\sim 84 \mathrm{Ma})$ older than the estimated eruption age (61 Ma) and displaying radiogenic initial Osisotope ratios $\left({ }^{187} \mathrm{Os} /{ }^{188} \mathrm{Os}=0.1431 \pm 4 ; \gamma \mathrm{Os}_{61 \mathrm{Ma}}=\sim+13\right)$. While some of the other Disko Island samples also lie along this isochron, it is difficult to estimate whether this is the case for all samples. This is because, while samples come from the same large-scale magmatic system, they may have resulted from different melt pulses and discrete mantle melting events. Indeed, the Disko Island Fe-bearing samples do not exhibit evidence for significant interelement HSE fractionations, and so, combined with evidence for disturbed Re-Os isotope systematics, these samples are consistent with the origin of native-Fe through concomitant assimilation and fractional crystallization with limited prior fractionation. 
It was only possible to analyse two splits from the Bühl native-Fe locality. Whereas anything less than three-point isochrons are of dubious reliability, together the two splits do not lie on a Miocene reference line in Re-Os isotope space. Instead the sample are consistent with variations seen in CEVP rocks, also apparently requiring assimilation of high ${ }^{187} \mathrm{Os} /{ }^{188} \mathrm{Os}$ crustal components during native-Fe crystallization (also see the $S O M$ ). The flat, relatively unfractionated HSE patterns, but disturbed Re-Os isotope systematics for Bühl and Disko Island, contrast with the fractionated HSE patterns, and broadly isochronous yet highly contaminated Re-Os isotope systematics of the Siberian occurrences. These results highlight that primitive and evolved melts that enter the upper crust can be recognized even after the formation of native-Fe during reduction from carbonaceous-sediment assimilation.

\subsection{Lower crustal contamination in Siberian samples}

For samples identified as requiring a stage of assimilation prior to native-Fe precipitation (e.g., Khungtukun and Dzhaltul), it is ambiguous from Re-Os isotope diagrams if such a stage took place within the lower- or upper-crust (Figure 6). This is in part due to the overlap of Re-Os isotope systematics for upper- and lower-crustal lithologies (Rudnick and Gao, 2003, and references therein). Upper crustal materials, especially shales, have distinct large ion lithophile (LILE) and high field strength element (HFSE) ratios with respect to lithologies such as gniesses and granitoids that are more commonly found in the lowercrust or the lowermost portions of the upper-crust (Taylor and McLennan, 1985). Ratios of the LILE/HFSE and inter-element HFSE ratios have been used to differentiate between the assimilation of the upper- versus the lower-crust (e.g., Hawkesworth et al., 1995; Lightfoot et al., 1997). Siberian samples, including those from the Nadezhdinsky and Siberian upperbasaltic suites (Mokvlaevsky, Morongosky, and Samoedsky suites), display $\mathrm{Zr} / \mathrm{Nb}$ and $\mathrm{Th} / \mathrm{Nb}$ versus $\mathrm{La} / \mathrm{Sm}$ trends that are broadly consistent with the assimilation of lower-crust, or the lowermost portions of the upper-crust, with limited upper-crust involvement (Figure 9). This implies that, prior to the crystallization of native-Fe, which must have taken place in the organic-sediment-rich regions of the upper-crust, the Siberian parental magmas acquired their initial radiogenic Os-isotope composition from lower-crustal assimilation. By contrast, Disko Island samples plot along higher $\mathrm{Th} / \mathrm{Nb}$ and $\mathrm{Zr} / \mathrm{Nb}$ trends than native-Fe bearing Siberian samples, overlapping picritic basalts reported from Disko Island. Such systematics, together with the Re-Os isotope system that displays non-isochronous relationships, indicate that 
upper-crustal contamination has dominated the chemical identity of Disko Island basalts (e.g., Lightfoot et al., 1997).

\subsection{Effect of carbonaceous sediment assimilation on volatile degassing}

Numerous studies have recognized the temporal association of the Siberian continental flood basalts with the end-Permian mass extinction (e.g., Reichow et al., 2009). The end-Permian 'great dying' is the largest known mass extinction event in Earth history, leading to $\sim 95 \%$ of all shell-bearing marine species and $\sim 80 \%$ of all known land animals ceasing to exist (Knoll et al., 2007). Numerous studies have advocated the mobilization of carbon from a combination of wildfires (e.g., Hudspith et al., 2014), $\mathrm{CO}_{2}$ release from mantle-derive eclogites (Sobolev et al., 2011), and mobilization of carbon from thick deposits of organic sediments on the Siberian platform that interacted with mafic melts (e.g., Retallack \& Jahren, 2008; Reichow et al., 2009; Ogden \& Sleep, 2012). Our work demonstrates that organic C-rich sediment-magma interactions have occurred, not just in the Siberian traps, but also in the North Atlantic LIP, and the CEVP.

Ogden and Sleep (2012) suggested a mechanism whereby magma-sediment interaction might result in the liberation of volatile greenhouse gases such as $\mathrm{CH}_{4}, \mathrm{CO}_{2}, \mathrm{CO}$, and $\mathrm{SO}_{2}$. They suggested that a 'mingled' magma-sediment mix would undergo oxidation during magmatic ascent, resulting in coal combustion, enabling the release of large volumes of gas. Indeed, the liberation of such gases has been suggested to account for the three major $\delta^{13} \mathrm{C}$-isotopic excursions at the end Permian. It has been shown that $2.3 \times 10^{17}$ moles of $\mathrm{C}$ would have to be released into the atmosphere, equating to approximately 1 trillion tonnes of C (Retallack \& Jahren, 2008). From the calculations of Ogden \& Sleep (2012), a combined volume of $\sim 1000 \mathrm{~km}^{3}$ of coal would need to be fully liberated and injected into the atmosphere, mostly as methane, to cause a singular atmospheric $\mathrm{C}$ isotopic excursion.

Our work shows that approximately 2 to $5 \%$ crustal contamination occurred to generate the localized occurrence of native-Fe metal in the Khungtukun and Dzhaltul intrusions. Although the volumes of the Khungtukun and Dzhaltul intrusions have not been accurately determined, based on mass balance calculation, they are probably both on the 
514 order of $<5000 \mathrm{~km}^{3}$. Whereas the Fe-bearing mafic rocks in these intrusions only represent a small proportion of the intrusive volume, this provides an absolute upper bound of consumption of between 100 to $250 \mathrm{~km}^{3}$ of crustal materials. Trace-element data for the Khungtukun and Dzhaltul intrusions also suggests that not all crustal material was organic/carbonaceous material (Section 4.3). Iacono-Marziano et al. (2012) suggested that < $\sim 0.5$ wt. \% assimilation of organic material was sufficient to generate the reducing conditions needed for native-Fe precipitation. Thus, it is likely that significantly less than 2 to $5 \%$ upper crustal (and therefore $<100$ to $250 \mathrm{~km}^{3}$ of crustal material) assimilation took place within the Khungtukun and Dzhaltul intrusions.

Assuming $100 \%$ of the crustal material was organic/carbonaceous material (i.e., $5 \%$ upper crustal assimilation) would require that the equivalent of approximately four Khungtukun/Dzhaltul-sized intrusions simultaneously degassed to account for a single $\delta^{13} \mathrm{C}$ isotopic excursion. Clearly, if assimilation of carbonaceous material was less efficient, as indicated by the results for the native-Fe bearing samples, then considerably $\left(10^{1}\right.$ to $\left.10^{3} \mathrm{x}\right)$ more carbonaceous sediment-basaltic melt interaction would be required. Understanding the potential effect of such interaction is important (e.g., Black et al., 2014), particularly as many models of atmospheric forcing during large-scale basaltic eruptions only account for volatiles released from the primitive, mantle-derived melts, and do not account for volatiles released from organic sediments assimilated by the melts (e.g., Schmidt et al., 2015). The calculations for assimilation of organic or carbonaceous crustal materials into Siberian magmas appears to preclude this mechanism as the sole cause of $\mathrm{C}$-isotope excursions during the Permo-Triassic mass extinction event. Nonetheless, the risk of significantly enhanced $\mathrm{CO}_{2}, \mathrm{CH}_{4}, \mathrm{CO}$ and $\mathrm{SO}_{2}$ emissions into the atmosphere by C-rich, sediment-basaltic melt interactions should not be underestimated, and is clearly not a globally or temporally isolated event, having occurred in at least three instances worldwide. Not only can these interactions lead to enhanced volcanicatmospheric exchange (c.f., Ogden \& Sleep, 2012), but significant interaction can occur between melts and organic sediments at shallow levels. Basaltic eruptions in pre-existing organic-rich sedimentary basins may have significantly enhanced effects on atmospheric conditions and, as such, are a major potential geohazard. Understanding the collateral effects of carbonaceous sediment assimilation by basaltic melts is an important and unresolved issue, especially given the increased probability of carbonaceous sediment-melt interactions within 
continents, or at continental rifted margins, relative to basaltic volcanism outside of continental areas, since the Phanerozoic.

\section{Conclusions}

Carbonaceous sediment-basalt melt interactions result in the formation of native-iron bearing mafic rocks and greenhouse gas by-products $\left(\mathrm{CH}_{4}, \mathrm{CO}, \mathrm{CO}_{2}, \mathrm{SO}_{2}, \mathrm{H}_{2} \mathrm{O}\right)$. The nativeiron basalt samples from this reaction present a unique opportunity to investigate magmacrust interactions under predominantly reducing $\left(f \mathrm{O}_{2}<\mathrm{IW}\right)$ conditions, in addition to assessing the collateral effects of volatile degassing. Samples from all three currently known localities of native iron in terrestrial mafic rocks (Siberia, Disko Island, Bühl) display radiogenic Os-isotopic compositions $\left(\gamma \mathrm{Os}_{\text {initial }}+15\right.$ to +193$)$ with respect to estimated parental melts $\left(\gamma \mathrm{Os}_{\text {initial }}<2\right)$, consistent with the assimilation of crustal components with high $\mathrm{Re} / \mathrm{Os}$ and ${ }^{187} \mathrm{Os} /{ }^{188} \mathrm{Os}$. Correlations between Os-isotopes and trace-element systematics indicate that all samples can be accounted for by 1 to $7 \%$ combined fractional crystallization and assimilation (AFC) of crustal materials. Internal Re-Os isotope systematics aid in constraining the timing of assimilation. Disko Island and Bühl samples lie on 'older' isochrons with respect to their estimated crystallization ages, indicating that significant crustal assimilation took place during the precipitation of native-Fe, or before complete mixing. In contrast, Siberian samples display internal isochrons that preserve the crystallization age of the host intrusions. This indicates that most contamination occurred prior to the precipitation of native-Fe in the Siberian intrusions. This is consistent with fractional crystallization modelling, which indicates that the relative HSE abundances are controlled by sulphide removal from the melt. Carbonaceous-sediment/basaltic-melt interactions have been cited extensively as a major contributing factor for mass extinction events such as the end-Permian 'Great-Dying'. Our results indicate that the effects of atmospheric forcing by degassing of volatile species $\left(\mathrm{CO}_{2}, \mathrm{CH}_{4}, \mathrm{CO}\right.$ and $\left.\mathrm{SO}_{2}\right)$ requires further detailed consideration, but that carbonaceous sediment-basaltic melt interactions alone do not appear to explain the large carbon-isotope excursions that occurred during the PermoTriassic mass extinction.

\section{Acknowledgments}


577

578

579

580

581

582

583

584

585

586

587

588

589

590

591

592

593

594

595

596

597

598

599

600

601

602

We are grateful to Cyrena Goodrich for providing samples from Disko Island, and for helpful comments during the preparation of this manuscript. We thank John Bird and Maura Weathers for providing the Bühl sample. Constructive comments by two reviewers and the editorial efforts of Prof. T. Mather are gratefully acknowledged. Funding from the National Science Foundation (NSF), Division of Earth Sciences (EAR-1116089 to JMDD; EAR1144337 to LAT) and a consolidated STFC grant ST/M001253/1 is gratefully acknowledged. Finally, we wish to thank the Planetary Geoscience Institute (UTK) for financial assistance.

\section{References}

Barnes, S. J., Zientek, M., \& Severson, M. (1997). Ni, Cu, Au, and platinum-group element contents of sulphides associated with intraplate magmatism: a synthesis. Canadian Journal of Earth Sciences, 34, 337-351.

Basu, A. R., Poreda, R. J., Renne, P. R., Teichmann, F., Vasiliev, Y. R., Sobolev, N. V., \& Turrin, B. D. (1995). High- ${ }^{3} \mathrm{He}$ plume origin and temporal-spatial evolution of the Siberian flood basalts. Science, 269, 822-825.

Birck, J. L., Barman, M. R., \& Capmas, F. (1997). Re-Os Isotopic Measurements at the Femtomole Level in Natural Samples. Geostandards newsletter, 21, 19-27.

Black, B. A., Lamarque, J. F., Shields, C. A., Elkins-Tanton, L. T., \& Kiehl, J. T. (2014).

Acid rain and ozone depletion from pulsed Siberian Traps magmatism. Geology, 42, 67-70.

603 
604

605

606

607

608

609

610

611

612

613

614

615

616

617

618

619

620

621

622

623

624

625

626

627

628

629

630

Carter, S. R., Evensen, N. M., Hamilton, P. J., and O’Nions, R. K. (1978) Neodymium and strontium isotope evidence for crustal contamination of Continental volcanics. Science 202, 743747.

Carlson, R. W., Lugmair, G. W., \& Macdougall, J. D. (1981). Columbia River volcanism: the question of mantle heterogeneity or crustal contamination. Geochimica et Cosmochimica Acta, 45, 2483-2499.

Chipman, J. 1973. C-Fe (Carbon-Iron), In Metals Handbook, Vol. 8 (8th ed.): Metals Park, Ohio, Am. Soc. for Metals, p. 275-278.

Clark, D. B., and Pedersen, A. K. (1976) Tertiary volcanic province of West Greenland. In; A. Escher and W. S. Watt (Editors), Geology of Greenland. Geol. Surv. Greenland, Copenhagen, pp. 364-385.

Cohen, A.S., Waters, F.G., (1996). Separation of osmiumfromgeologicalmaterials by solvent extraction for analysis by thermal ionisation mass spectrometry. Analytica Chimica Acta 332, $269-275$.

Cox K. G. (1980) A model for flood basalt vulcanism. J. Petrol. 21, 629-650.

Crocket, J. H., \& MacRae, W. E. (1986). Platinum-group element distribution in komatiitic and tholeiitic volcanic rocks from Munro Township, Ontario. Economic Geology, 81, 12421251.

Dale, C. W., Pearson, D. G., Starkey, N. A., Stuart, F. M., Ellam, R. M., Larsen, L. M., \& Macpherson, C. G. (2009). Osmium isotopes in Baffin Island and West Greenland picrites: 
631 implications for the ${ }^{187} \mathrm{Os} /{ }^{188}$ Os composition of the convecting mantle and the nature of high

$632{ }^{3} \mathrm{He} /{ }^{4} \mathrm{He}$ mantle. Earth and Planetary Science Letters, 278, 267-277.

633

Dale, C. W., Macpherson, C. G., Pearson, D. G., Hammond, S. J., \& Arculus, R. J. (2012). Inter-element fractionation of highly siderophile elements in the Tonga Arc due to flux melting of a depleted source. Geochimica et Cosmochimica Acta, 89, 202-225.

637

Day, J.M.D. (2013). Hotspot volcanism and highly siderophile elements. Chemical Geology, 639 $341,50-74$.

640

Day, J.M.D. (2016). Evidence against a non-chondritic mantle source for North Atlantic Igneous Province lavas. Chemical Geology, 440, 91-100.

Day J.M.D., Peters B.J., Janney P.E. (2014) Oxygen isotope systematics of South African olivine melilitites and implications for HIMU mantle reservoirs. Lithos, 202-203, 76-84.

646

Day, J.M.D., Pearson, D.G., \& Hulbert, L.J. (2013). Highly siderophile element behaviour during flood basalt genesis and evidence for melts from intrusive chromitite formation in the Mackenzie large igneous province. Lithos, 182, 242-258.

650

651 Day J.M.D., Waters C. L., Schaefer B. F., Walker R. J., \& Turner, S. (2016). Use of 652 Hydrofluoric Acid Desilicification in the Determination of Highly Siderophile Element 653 Abundances and Re-Pt-Os Isotope Systematics in Mafic-Ultramafic Rocks. Geostandards and 654 Geoanalytical Research, 40, 49-65.

655

656 Day, J.M.D., Corder, C.A., Cartigny, P., Steele, A.M., Assayag, N., Rumble, D., Taylor, L.A. 657 (2017) A carbon-rich region in Miller Range 091004 and implications for ureilite 658 petrogenesis. Geochimica et Cosmochimica Acta. 10.1016/j.gca.2016.11.026 
660 Frost, B. R. (1991). Introduction to oxygen fugacity and its petrologic importance. Reviews 661 in Mineralogy and Geochemistry, 25, 1-9.

662

663 Goodrich, C. A., \& Patchett, P. J. (1991). Nd and Sr isotope chemistry of metallic iron664 bearing, sediment-contaminated Tertiary volcanics from Disko Island, Greenland. Lithos, 27, 665 13-27.

666

667 Hawkesworth, C. J., Lightfoot, P. C., Fedorenko, V. A., Blake, S., Naldrett, A. J., Doherty, 668 W., \& Gorbachev, N. S. (1995). Magma differentiation and mineralisation in the Siberian 669 continental flood basalts. Lithos, 34, 61-88.

670

671 Horan, M. F., Walker, R. J., Morgan, J. W., Grossman, J. N., \& Rubin, A. E. (2003). Highly 672 siderophile elements in chondrites. Chemical Geology, 196, 27-42.

673

674 Hudspith, V. A., Rimmer, S. M., \& Belcher, C. M. (2014). Latest Permian chars may derive 675 from wildfires, not coal combustion. Geology, 42, 879-882.

676

677 Iacono-Marziano, G., Marecal, V., Pirre, M., Gaillard, F., Arteta, J., Scaillet, B., \& Arndt, N. 678 T. (2012). Gas emissions due to magma-sediment interactions during flood magmatism at the 679 Siberian Traps: Gas dispersion and environmental consequences. Earth and Planetary Science 680 Letters, 357, 308-318.

681

682 Ireland, T. J., Walker, R. J., \& Garcia, M. O. (2009). Highly siderophile element and 187 Os 683 isotope systematics of Hawaiian picrites: implications for parental melt composition and 684 source heterogeneity. Chemical Geology, 260, 112-128. 
686

687

688

689

690

691

692

693

694

695

696

697

698

699

700

701

702

703

704

705

706

707

708

709

710

711

712

713

Jamais, M., Lassiter, J. C., \& Brügmann, G. (2008). PGE and Os-isotopic variations in lavas from Kohala Volcano, Hawaii: constraints on PGE behavior and melt/crust interaction.

Chemical Geology, 250, 16-28.

Jung, S., \& Hoernes, S. (2000). The major-and trace-element and isotope ( $\mathrm{Sr}, \mathrm{Nd}, \mathrm{O})$ geochemistry of Cenozoic alkaline rift-type volcanic rocks from the Rhön area (central Germany): petrology, mantle source characteristics and implications for asthenospherelithosphere interactions. Journal of Volcanology and Geothermal Research, 99, 27-53.

Jung, S., Pfänder, J. A., Brügmann, G., \& Stracke, A. (2005). Sources of primitive alkaline volcanic rocks from the Central European Volcanic Province (Rhön, Germany) inferred from $\mathrm{Hf}$, Os and $\mathrm{Pb}$ isotopes. Contributions to Mineralogy and Petrology, 150, 546-559.

Kamo, S. L., Czamanske, G. K., Amelin, Y., Fedorenko, V. A., Davis, D. W., \& Trofimov, V. R. (2003). Rapid eruption of Siberian flood-volcanic rocks and evidence for coincidence with the Permian-Triassic boundary and mass extinction at 251 Ma. Earth and Planetary Science Letters, 214, 75-91.

Knoll, A. H., Bambach, R. K., Payne, J. L., Pruss, S., \& Fischer, W. W. (2007). Paleophysiology and end-Permian mass extinction. Earth and Planetary Science Letters, 256, 295-313.

Klöck W, Palme H, Tobschall H (1986) Trace elements in natural metallic iron from Disko Island, Greenland. Contributions to mineralogy and petrology 93:273-282

Larsen, L. M., \& Pedersen, A. K. (2009). Petrology of the Paleocene picrites and flood basalts on Disko and Nuussuaq, West Greenland. Journal of petrology, 50, 1667-1711. 
714

715

716

717

718

719

720

721

722

723

724

725

726

727

728

729

730

731

732

733

734

735

736

737

738

739

740

741

742

Li, C., Tao, Y., Qi, L., \& Ripley, E. M. (2012). Controls on PGE fractionation in the

Emeishan picrites and basalts: constraints from integrated lithophile-siderophile elements and $\mathrm{Sr}-\mathrm{Nd}$ isotopes. Geochimica et Cosmochimica Acta, 90, 12-32.

Lightfoot, P. C., \& Hawkesworth, C. J. (1997). Flood basalts and magmatic Ni, Cu, and PGE sulphide mineralization: comparative geochemistry of the Noril'sk (Siberian Traps) and West Greenland sequences. Large igneous provinces: continental, oceanic, and planetary flood volcanism, 357-380.

Lightfoot, P. C., \& Keays, R. R. (2005). Siderophile and chalcophile metal variations in flood basalts from the Siberian trap, Noril'sk region: Implications for the origin of the Ni-Cu-PGE sulfide ores. Economic Geology, 100, 439-462.

Lightfoot, P. C., Hawkesworth, C. J., Hergt, J., Naldrett, A. J., Gorbachev, N. S., Fedorenko, V. A., \& Doherty, W. (1993). Remobilisation of the continental lithosphere by a mantle plume: major-, trace-element, and $\mathrm{Sr}-, \mathrm{Nd}$, and $\mathrm{Pb}$-isotope evidence from picritic and tholeiitic lavas of the Noril'sk District, Siberian Trap, Russia. Contributions to Mineralogy and Petrology, 114, 171-188.

Lightfoot, P. C., \& Hawkesworth, C. J. (1997). Flood basalts and magmatic Ni, Cu, and PGE sulphide mineralization: comparative geochemistry of the Noril'sk (Siberian Traps) and West Greenland sequences. Large igneous provinces: continental, oceanic, and planetary flood volcanism, 357-380.

Lippolt, H. J. (1982). K/Ar age determinations and the correlation of Tertiary volcanic activity in Central Europe. Geol Jb D, 52, 113-135.

Ludwig, K. R. (2009). Isoplot v. 3.71: a geochronological toolkit for Microsoft Excel: Berkeley. California, Berkeley Geochronology Center Special Publication, 4, 70. 
McDonough, W. F., \& Sun, S. S. (1995). The composition of the Earth. Chemical geology, 120, 223-253.

747

Mittlefehldt, D. W. (1990). Petrogenesis of mesosiderites: I. Origin of mafic lithologies and comparison with basaltic achondrites. Geochimica et Cosmochimica Acta, 54, 1165-1173.

750

751

752

753

754

755

756

757

758

759

760

761

762

763

764

765

766

767

768

769

Monders, A.G., Médard, E., Grove, T.L. (2007), Phase equilibrium investigations of the Adirondack class basalts from the Gusev plains, Gusev crater, Mars. Meteoritics and Planetary Science, 42, 131-148.

Mungall, J. E., \& Brenan, J. M. (2014). Partitioning of platinum-group elements and Au between sulfide liquid and basalt and the origins of mantle-crust fractionation of the chalcophile elements. Geochimica et Cosmochimica Acta, 125, 265-289.

Papike, J., Taylor, L., \& Simon, S. (1991). Lunar minerals. Lunar sourcebook, 121-181.

Peucker-Ehrenbrink, B., \& Jahn, B. M. (2001). Rhenium-osmium isotope systematics and platinum group element concentrations: Loess and the upper continental crust. Geochemistry, Geophysics, Geosystems, 2(10).

Reichow, M. K., Pringle, M. S., Al'Mukhamedov, A. I., Allen, M. B., Andreichev, V. L., Buslov, M. M., \& Saunders, A. D. (2009). The timing and extent of the eruption of the Siberian Traps large igneous province: Implications for the end-Permian environmental crisis. Earth and Planetary Science Letters, 277, 9-20. 
Retallack, G. J., \& Jahren, A. H. (2008). Methane release from igneous intrusion of coal during Late Permian extinction events. The Journal of Geology, 116, 1-20.

Righter, K., Danielson, L. R., Pando, K. M., Williams, J., Humayun, M., Hervig, R. L., \& Sharp, T. G. (2015). Highly siderophile element (HSE) abundances in the mantle of Mars are due to core formation at high pressure and temperature. Meteoritics \& Planetary Science, 50, 604-631.

Rocha-Junior, E. R., Puchtel, I. S., Marques, L. S., Walker, R. J., Machado, F. B., Nardy, A. J., \& Figueiredo, A. M. (2012). Re-Os isotope and highly siderophile element systematics of the Paraná continental flood basalts (Brazil). Earth and Planetary Science Letters, 337, 164173.

Retallack, G. J., Metzger, C. A., Greaver, T., Jahren, A. H., Smith, R. M., \& Sheldon, N. D. (2006). Middle-Late Permian mass extinction on land. Geological Society of America Bulletin, 118(11-12), 1398-1411.

Ryabov, V. V., Shevko, A. Y., \& Gora, M. P. (2014). Immiscibility in Glasses from the Siberian Platform Traps. In Trap Magmatism and Ore Formation in the Siberian Noril'sk Region (pp. 621-624). Springer Netherlands.

Saunders, A. D., Fitton, J. G., Kerr, A. C., Norry, M. J., \& Kent, R. W. (1997). The north Atlantic igneous province. Geophysical Monograph-Anerican Geophyical Union, 100, 45-94.

Schmidt, A., Skeffington, R. A., Thordarson, T., Self, S., Forster, P. M., Rap, A., \& Wignall, P. B. (2015). Selective environmental stress from sulphur emitted by continental flood basalt eruptions. Nature Geoscience. 
801

802

803

804

805

806

807

808

809

810

811

812

813

814

815

816

817

818

819

820

821

822

823

824

Selby, D., Creaser, R. A., Stein, H. J., Markey, R. J., \& Hannah, J. L. (2007). Assessment of the $187 \mathrm{Re}$ decay constant by cross calibration of Re-Os molybdenite and U-Pb zircon chronometers in magmatic ore systems. Geochimica et Cosmochimica Acta, 71, 1999-2013.

Shirey, S. B., \& Walker, R. J. (1998). The Re-Os isotope system in cosmochemistry and high-temperature geochemistry. Annual Review of Earth and Planetary Sciences, 26, 423500 .

Sobolev, S. V., Sobolev, A. V., Kuzmin, D. V., Krivolutskaya, N. A., Petrunin, A. G., Arndt, N. T., \& Vasiliev, Y. R. (2011). Linking mantle plumes, large igneous provinces and environmental catastrophes. Nature, 477, 312-316.

Storey, M., Duncan, R. A., Pedersen, A. K., Larsen, L. M., \& Larsen, H. C. (1998). 40 Ar/39

Ar geochronology of the West Greenland Tertiary volcanic province. Earth and Planetary Science Letters, 160, 569-586.

Taylor, S. R., \& McLennan, S. M. (1985). The continental crust: its composition and evolution.

Taylor, L. A., Williams, R. J., \& McCallister, R. H. (1972). Stability relations of ilmenite and ulvöspinel in the Fe-Ti-O system and application of these data to lunar mineral assemblages. Earth and Planetary Science Letters, 16, 282-288.

Woodland, S. J., (2000). Development of ICP-MS Isotope Dilution Preconcentration Techniques for Determination of Platinum Group Elements in Volcanic Rocks. Ph.D. Thesis University of Durham. 
825 Woodland, S. J., Pearson, D. G., \& Thirlwall, M. F. (2002). A platinum group element and $826 \mathrm{Re}-\mathrm{Os}$ isotope investigation of siderophile element recycling in subduction zones: 827 comparison of Grenada, Lesser Antilles Arc, and the Izu-Bonin Arc. Journal of Petrology, $828 \quad 43,171-198$.

829

830 Wimmenauer, W., 1974. The alkaline province of Central Europe and France. In: Sorensen, 831 H. (Ed.), The Alkaline Rocks. Wiley, London, pp. 238-270.

832

833 Zientek, M. L., Likhachev, A. P., Kunilov, V. E., Barnes, S. J., Meier, A. L., Carlson, R. R., $834 \&$ Naldrett, A. J. (1994). Cumulus processes and the composition of magmatic ore deposits: 835 examples from the Talnakh district, Russia. In: Proceedings of the Sudbury-Noril'sk 836 symposium (pp. 373-392). 
837

838

839

840

841

842

843

844

845

846

847

848

849

850

851

852

853

854

855

856

857

858

859

860

861

862

863

864

865

866

\section{Figure captions:}

Figure 1: Location maps of magmatic provinces hosting native-Fe bearing basalts from: (a) the Dzhaltul and Khungtukun intrusions, at the edge of the Siberian craton; (b) the Hammers Dal complex and associated native-Fe bearing basalt occurrences of West Greenland, and the (c) the Bühl occurrence in the Central European Magmatic Province. Maps are after Ryabov et al., 2014, Goodrich and Patchett 1991, and Blusztajn and Hegner 2002.

Figure 2: Chondrite normalized REE profiles and Primitive-mantle (PM) normalised incompatible trace-element profiles for a) the Khungtukun intrusion, b) the Dzhaltul intrusion, and c) West Greenland (black lines) and Bühl (grey line), and d) West Greenland sediments. Chondrite and PM normalization values are taken from McDonough and Sun (1995).

Figure 3: Average total HSE concentrations (for Os, Ir, Ru, Pt, Pd and Re, in $\mu \mathrm{g} \mathrm{g}^{-1}$ ) versus $\mathrm{Ni}\left(\mu \mathrm{g} \mathrm{g}^{-1}\right)$ and $\mathrm{Fe}($ wt. \%) for Siberian, Disko Island, and Bühl samples.

Figure 4: CI-chondrite normalized HSE patterns for (a) the Khungtukun intrusion (Siberia), (b) the Dzhaltul intrusion (Siberia), (c) West Greenland, and (d) Bühl samples. Comparative data (grey fields) are for whole-rock Noril'sk sulfide-ore from Barnes et al. (2006); Lower Talakh and Lower Noril'sk data from Zientek et al. (1994); Tuklonsky picrite data from Keays and Lightfoot (2007); 4.6 to 7.1 wt. \% MgO basalts data from Rocha-Junior et al. (2012); West Greenland picrites are from Woodland (2000); Central German volcanic rocks Re and Os abundance data are from Blusztajn and Hegner (2002) and Jung et al. (2005) (crosses), and average alkali basalt data are from Day (2013). CI-chondrite normalization from Horan et al. (2003).

Figure 5: Chondrite normalized HSE patterns for a) West Greenland sediments and b) West Greenland crustal xenoliths. CI-chondrite normalizing data from Horan et al. (2003). Red line represents the average upper continental crustal value, after Peucker-Ehrenbrink and Jahn, (2001). 
868 Figure 6: ${ }^{187} \mathrm{Re} /{ }^{188} \mathrm{Os}-{ }^{187} \mathrm{Os} /{ }^{188} \mathrm{Os}$ diagrams for metalliferous samples from (a) the 869 Khungtukun intrusion; (b) the Dzhaltul intrusion, (c) Disko Island samples and regression of 870 sample WGLB, and d) Bühl samples. Samples from other Central German volcanic fields are 871 plotted in d) for comparison (Blusztajn and Henger, 2002; Jung et al., 2005). Isochron regression was calculated using Isoplot 3.7 (Ludwig, 2009); in cases where error bars are not present the symbol sizes are larger than external analytical uncertainties.

Figure 7: Chondrite normalized HSE patterns for select Siberian and Disko Island samples with model fractional crystallizations trends starting from an average picritic West Greenland composition (Woodland, 2000). Due to the cumulate nature of samples it is difficult to use the absolute HSE values to assess fractional crystallization, however, the relative fractionations are not strongly affected, and can thus be compared to the modelled variations in order to assess the role fractional crystallization has played in fractionating PPGE/IPGE ratios. In order to compare relative HSE variations of WGLB and HC80 with modelled variations, abundances of these samples have been divided by a factor of 100 . Fractional crystallization trajectories were calculated using bulk D values from Mungall and Brenan (2014). CI-chondrite normalization from Horan et al. (2003). See main text for details.

Figure 8: Effects of combined fractional crystalization and crustal contamination using average age-corrected initial ${ }^{187} \mathrm{Os} /{ }^{188} \mathrm{Os}$ versus average $[\mathrm{La} / \mathrm{Sm}]_{\mathrm{CI}}$ for all localities. Uncertainties (black bars) represent the range of values yielded by repeat digestions of the same sample. A starting picritic parental melt $\left([\mathrm{La} / \mathrm{Sm}]_{\mathrm{CI}} 1.3\right)$ and alkali-basaltic parental melt $\left([\mathrm{La} / \mathrm{Sm}]_{\mathrm{CI}} 2.1\right)$, both with variable Os content $\left(0.1\right.$ and $\left.1 \mathrm{ng} \mathrm{g}^{-1}\right),{ }^{187} \mathrm{Os} /{ }^{188} \mathrm{Os}$ of 0.127 was used. The average composition of the Disko Island sediments was assumed as the assimilant, providing an upper limit to the extent of upper crustal assimilation. However, we note that the extent of combined lower crustal may act to lower the amount of upper crustal assimilation required. The field of picritic compositions are from Dale et al. (2009) and Lightfoot et al. (1997) and represent samples from West Greenland and Siberia. The field of alkali basalts are from (Jung and Hoernes, 2000) and represent samples from Central 
$899 \quad$ Figure 9: $\mathrm{Th} / \mathrm{Nb}$ and $\mathrm{Zr} / \mathrm{Nb}$ versus $\mathrm{La} / \mathrm{Sm}$ plots for native-Fe samples (black symbols). Blue 900 crosses represent upper-crustal compositions data compiled within Rudnick and Gao (2003).

901 Blue squares represent West Greenland sediment data from this study. Red crosses represent 902 average lower-crustal compositions (data compiled within Rudnick and Gao, 2003). Disko 903 island picrite and basalts data from Lightfoot et al. (1997), Siberian picrites (Tuklonsky and 904 Gudchikhinsky suites) and basalt (Nadezhinsky, Morongovsky, Mokvlaevsky, and 905 Samoedsky suites) data are from Lightfoot et al. (1993), and Hawkesworth et al. (1995). 906 Black lines illustrate representative AFC trajectories between a picritic composition and 907 average an average upper-crustal composition (line 1) and average lower-crustal composition 908 (line 2). As with Re-Os isotope AFC models, an r value of 0.8 was used. For details of end909 member compositions used, please refer to the SOM. 

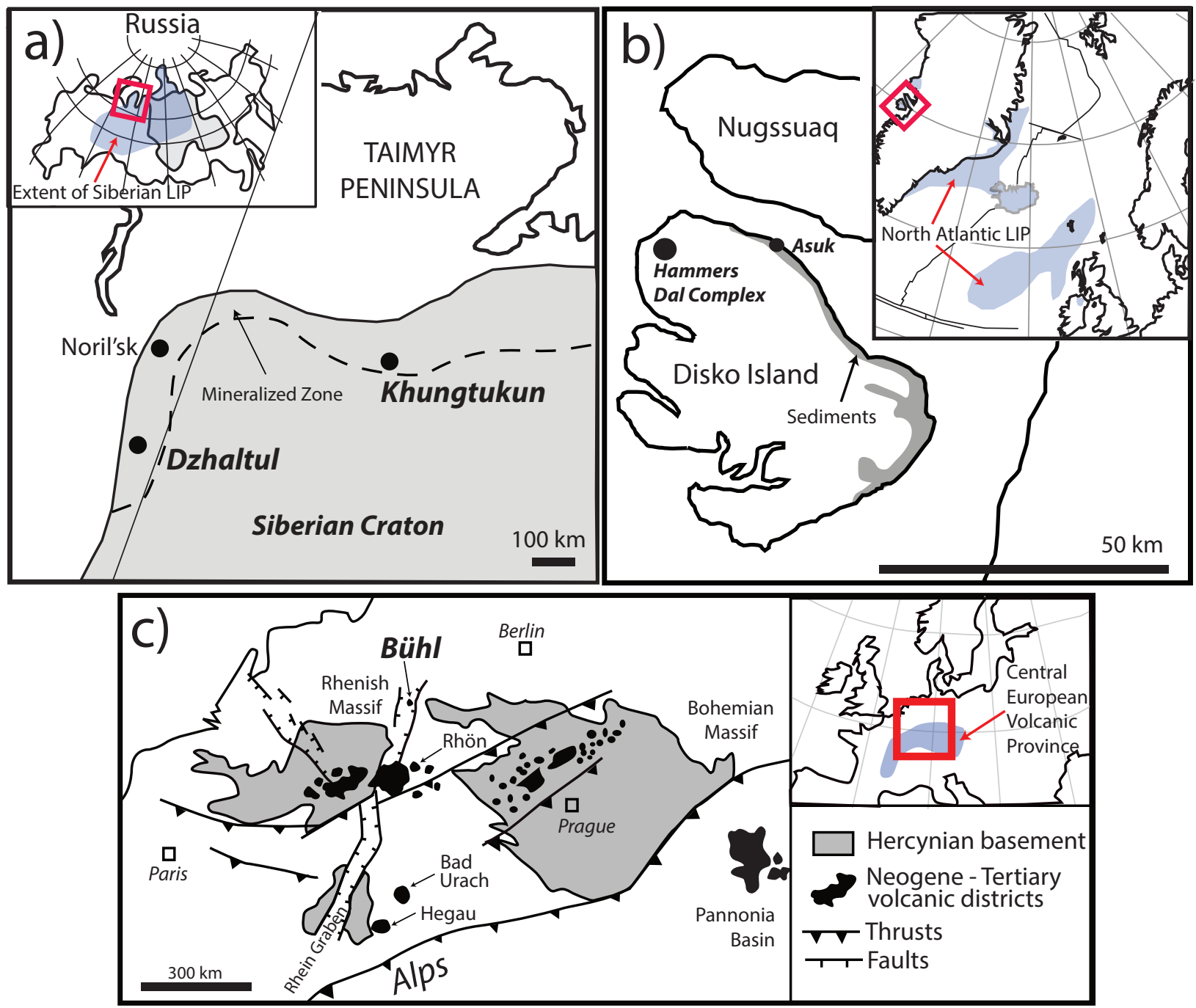

\section{Figure 1}



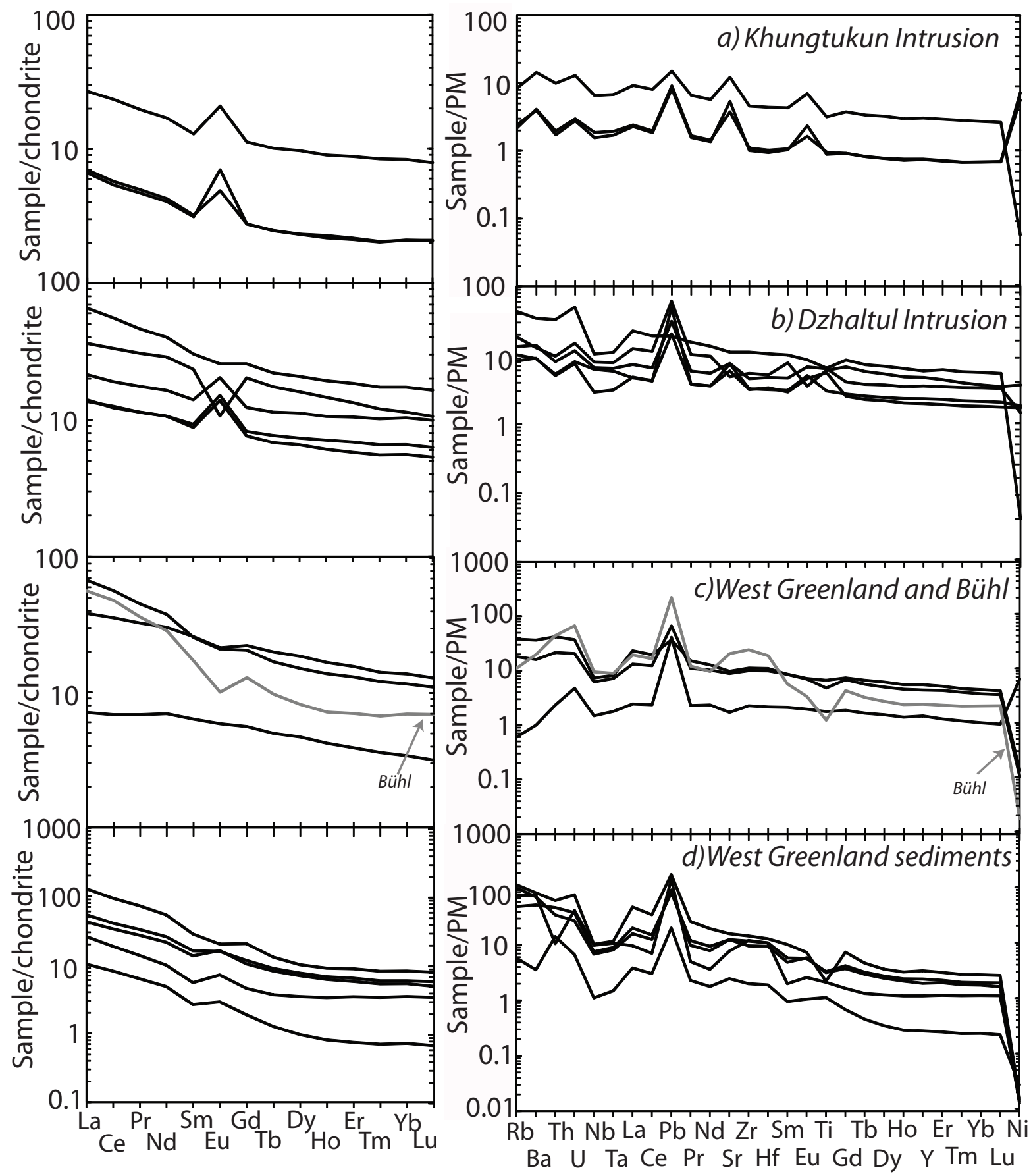

Figure 2 
Figure 3
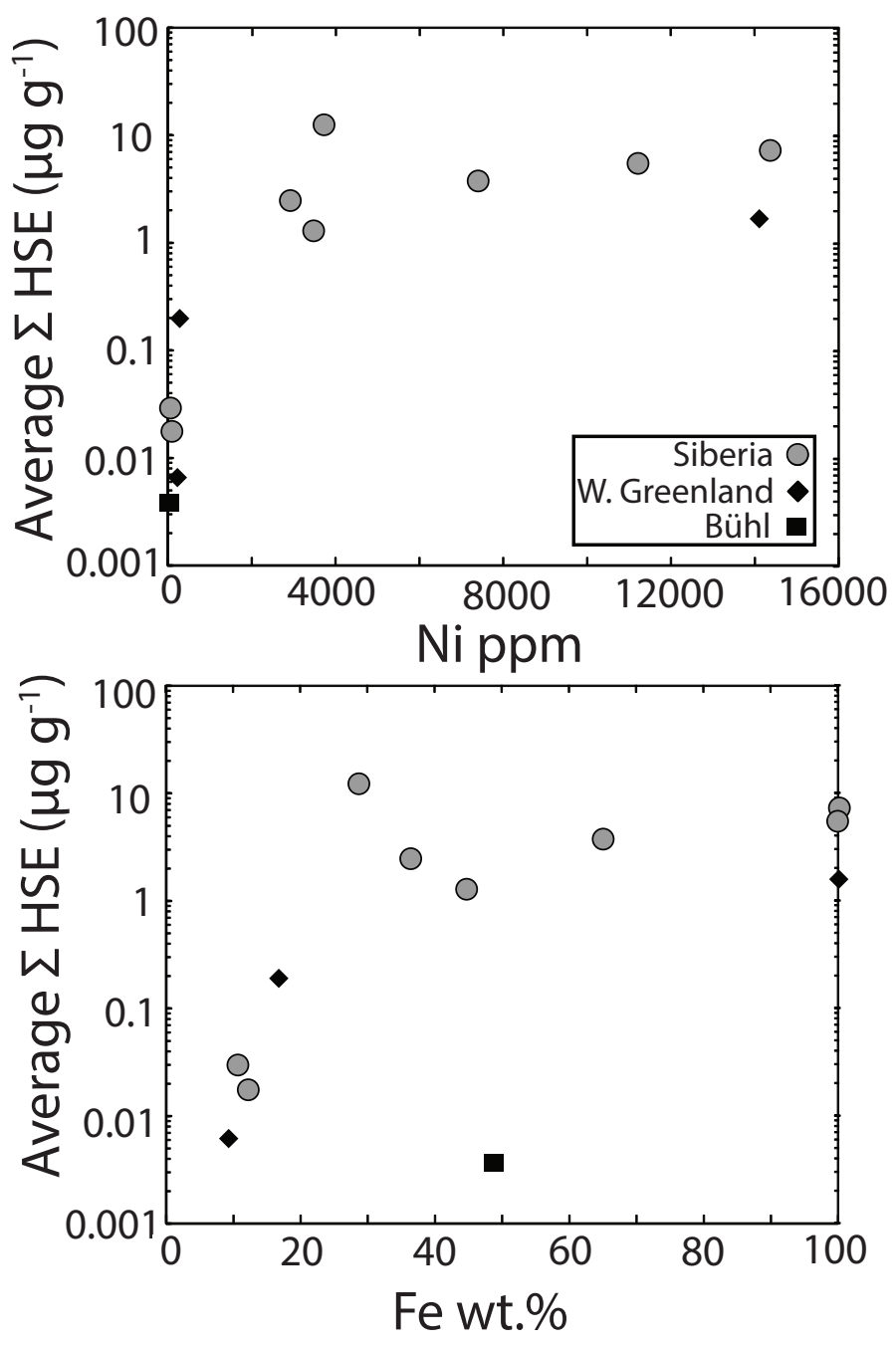

Fig. 3 
a)

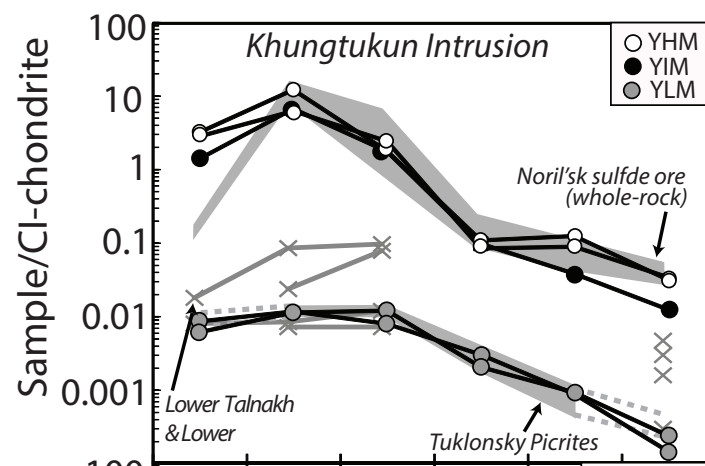

b)

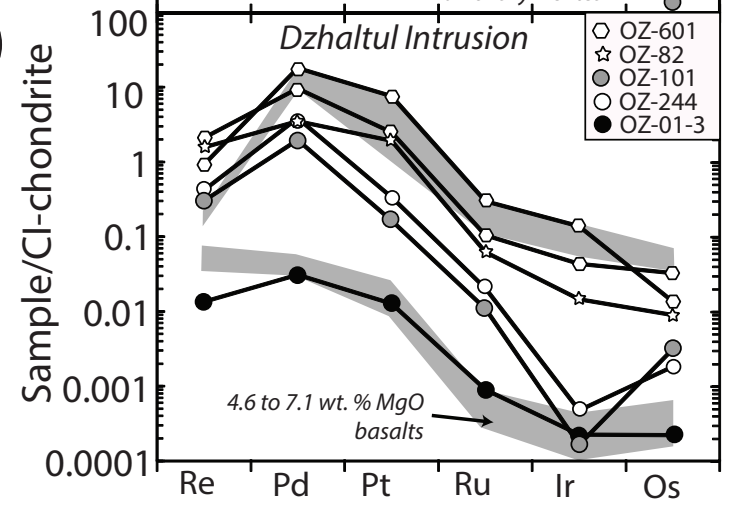

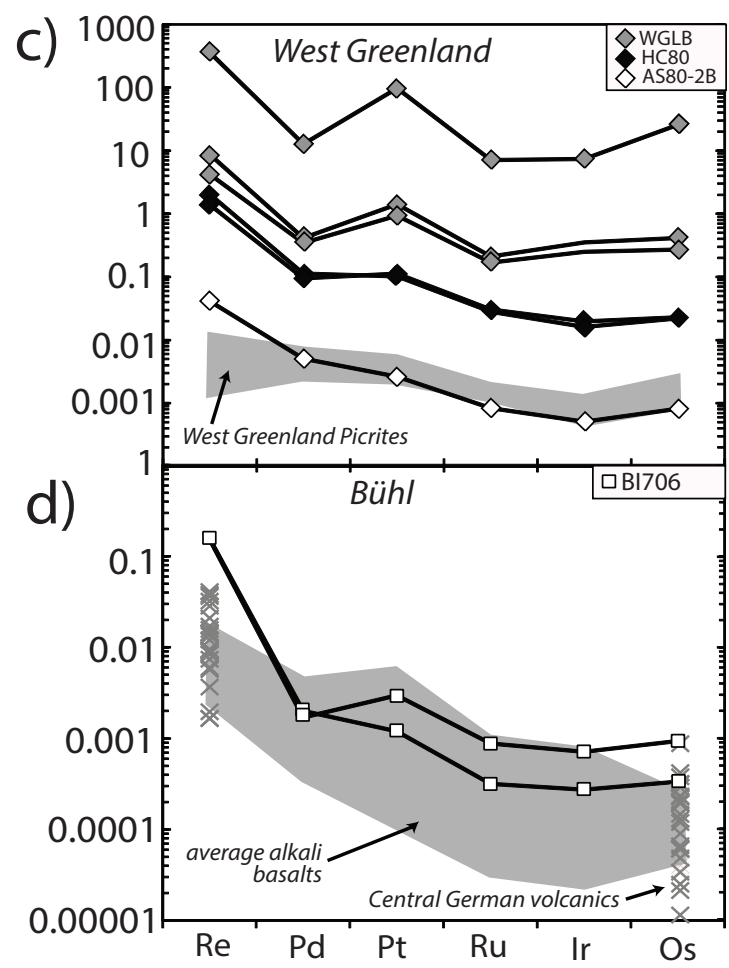

Figure 4 
Figure 5

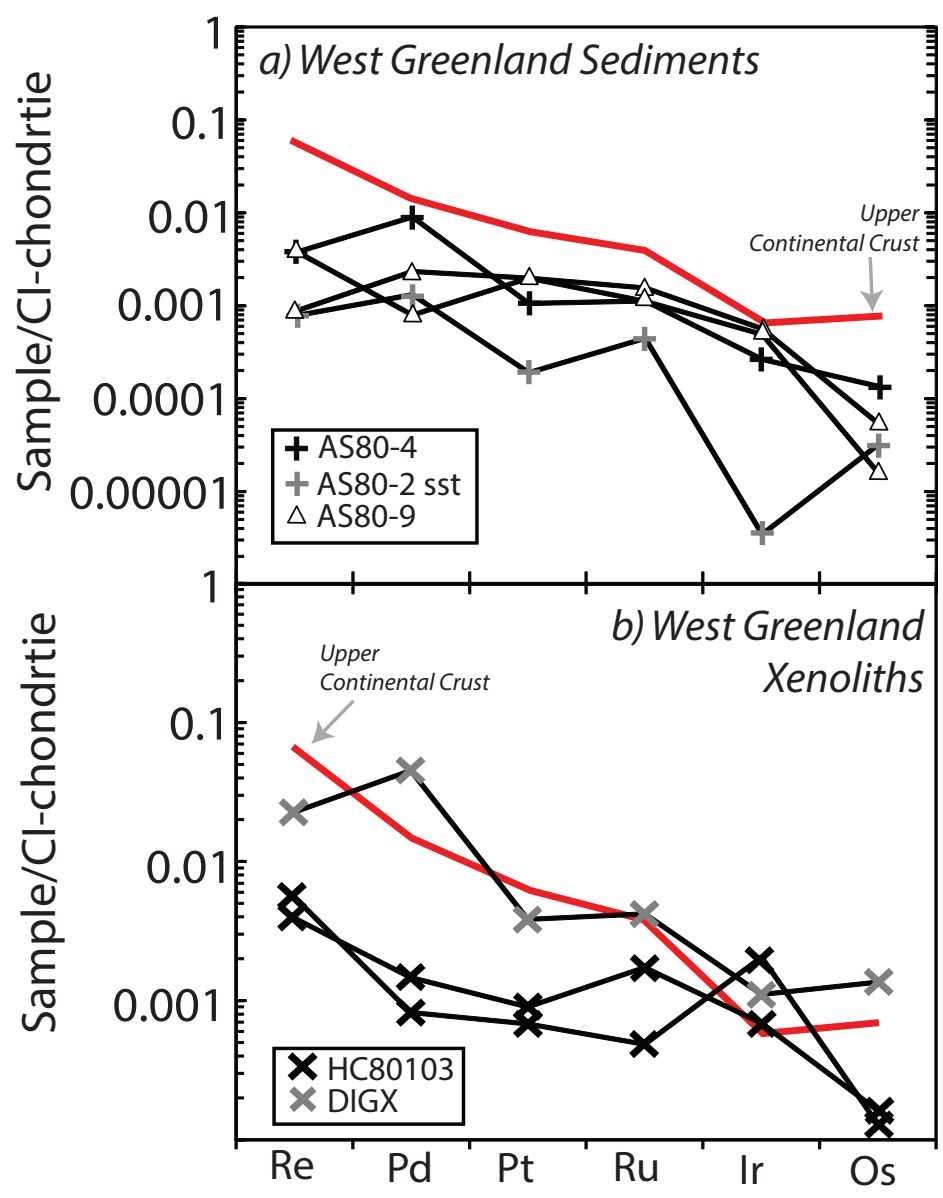

Figure 5 


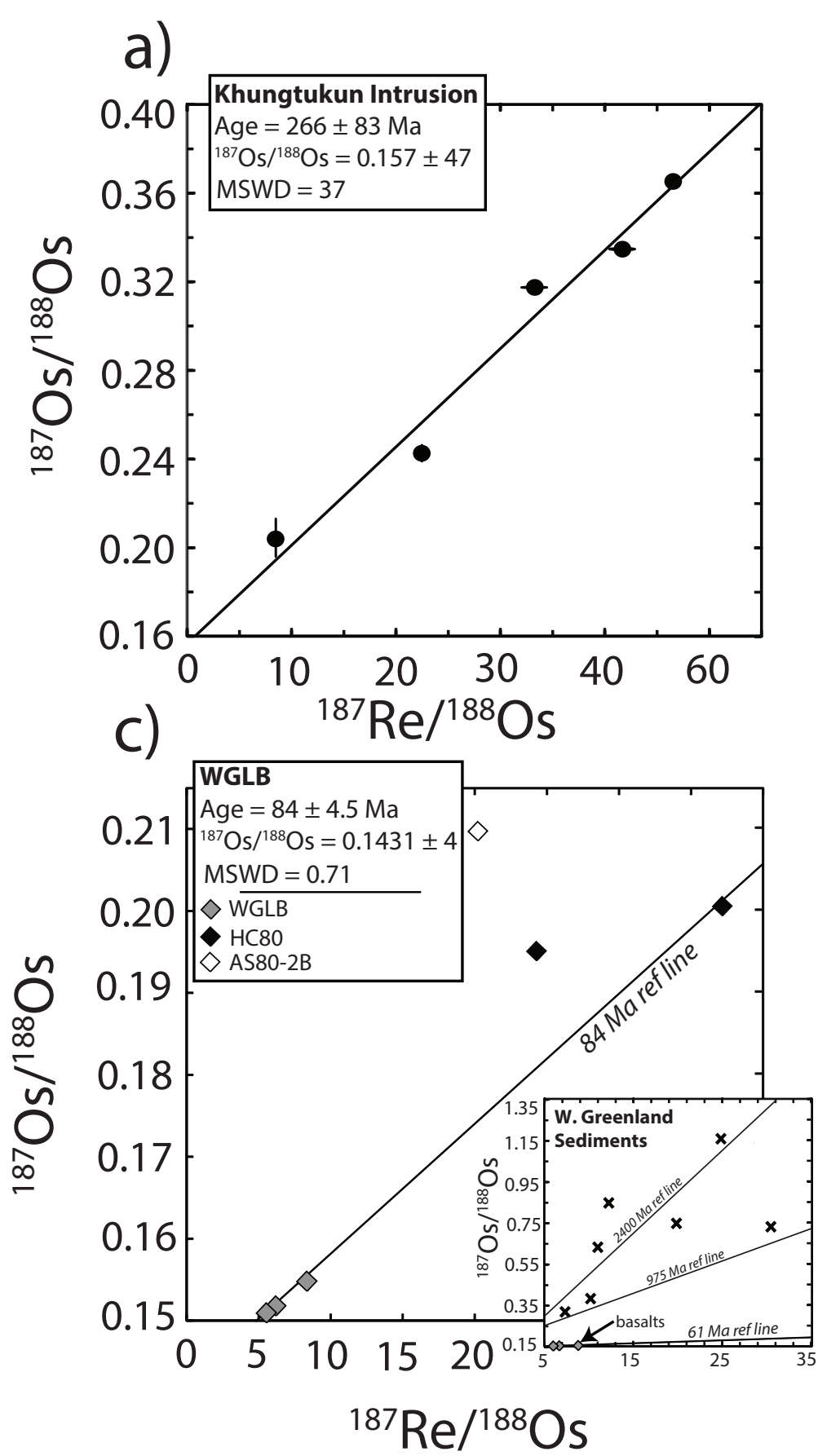

b)
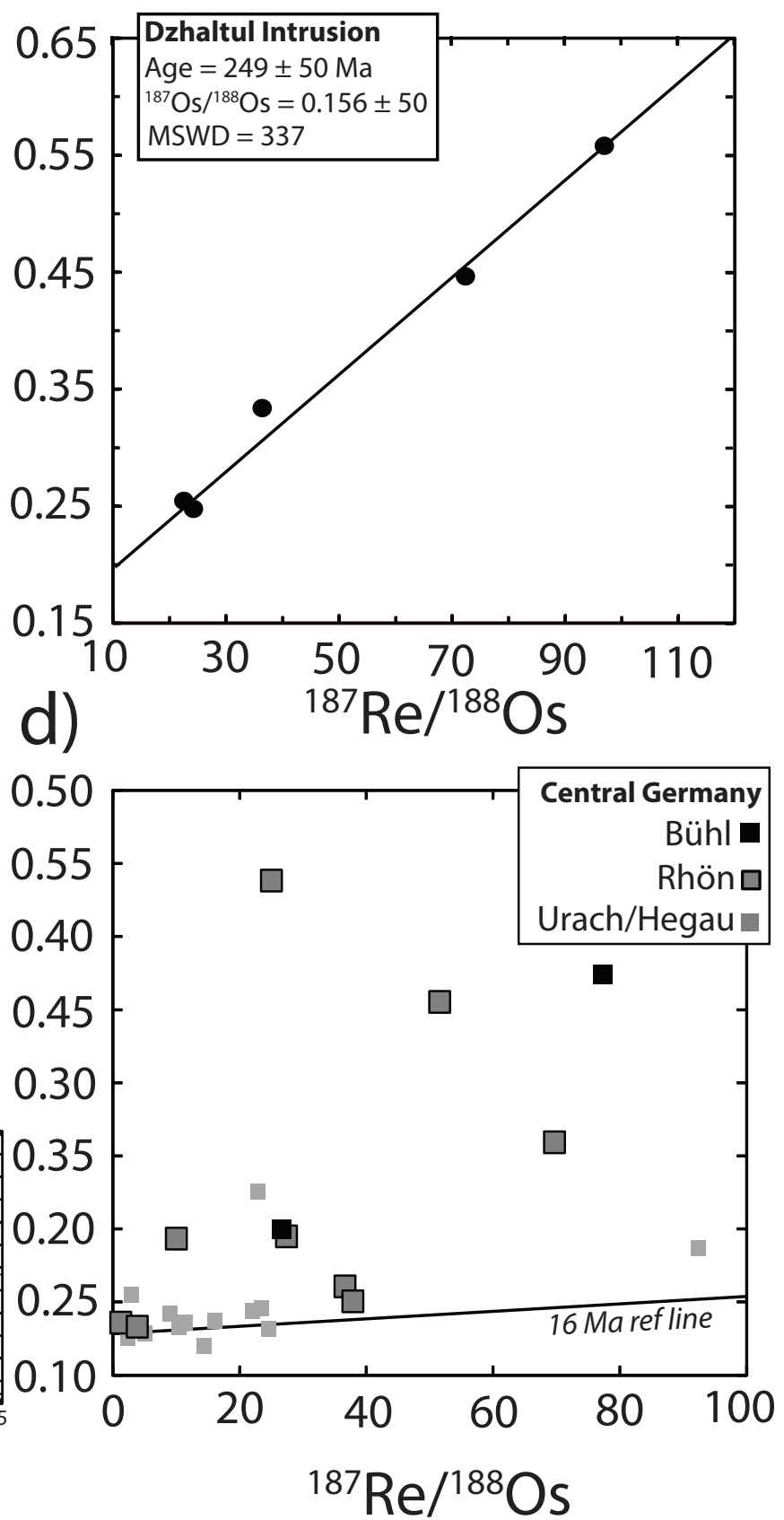

Figure 6 
Figure 7

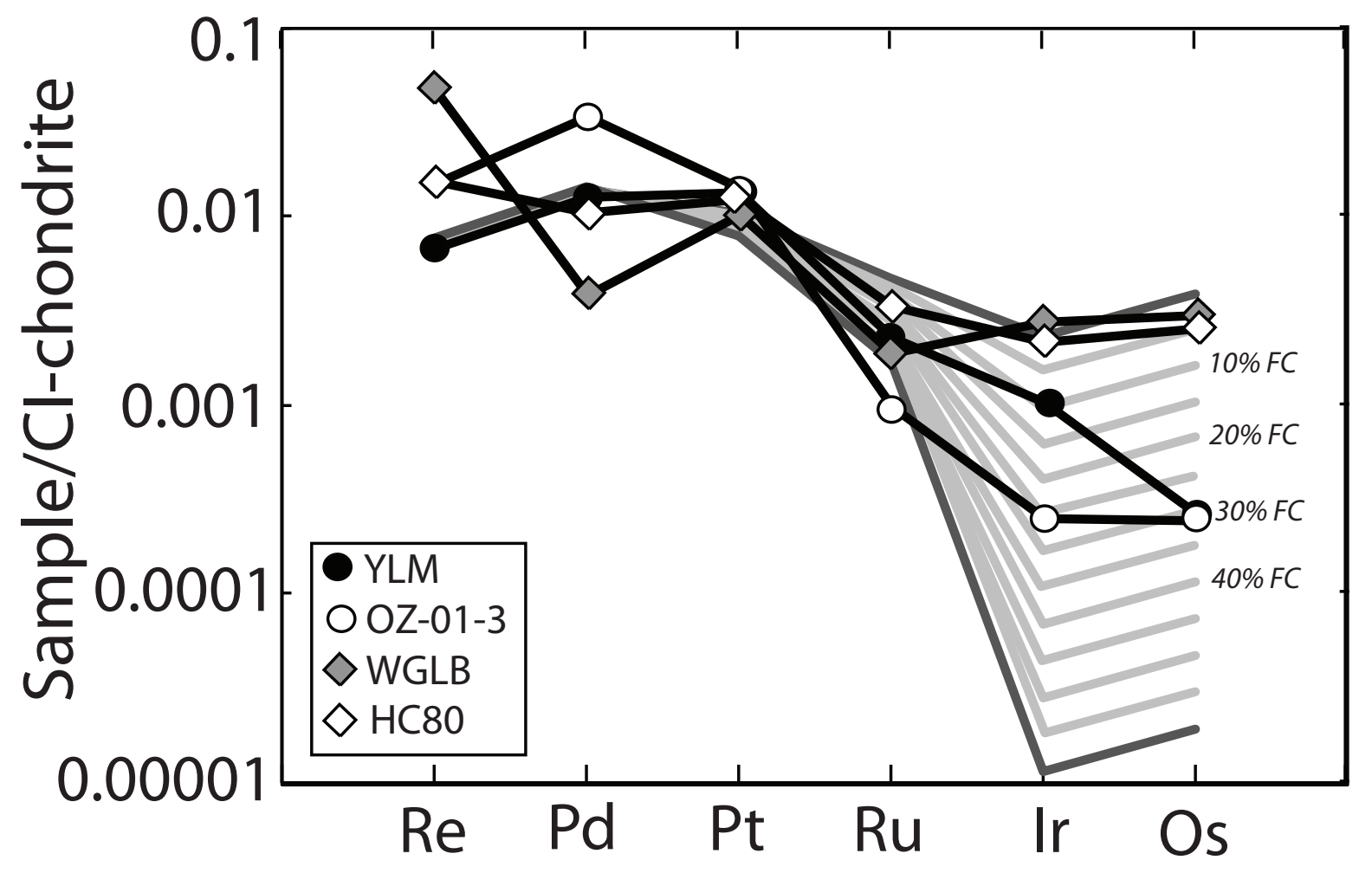

Figure 7 


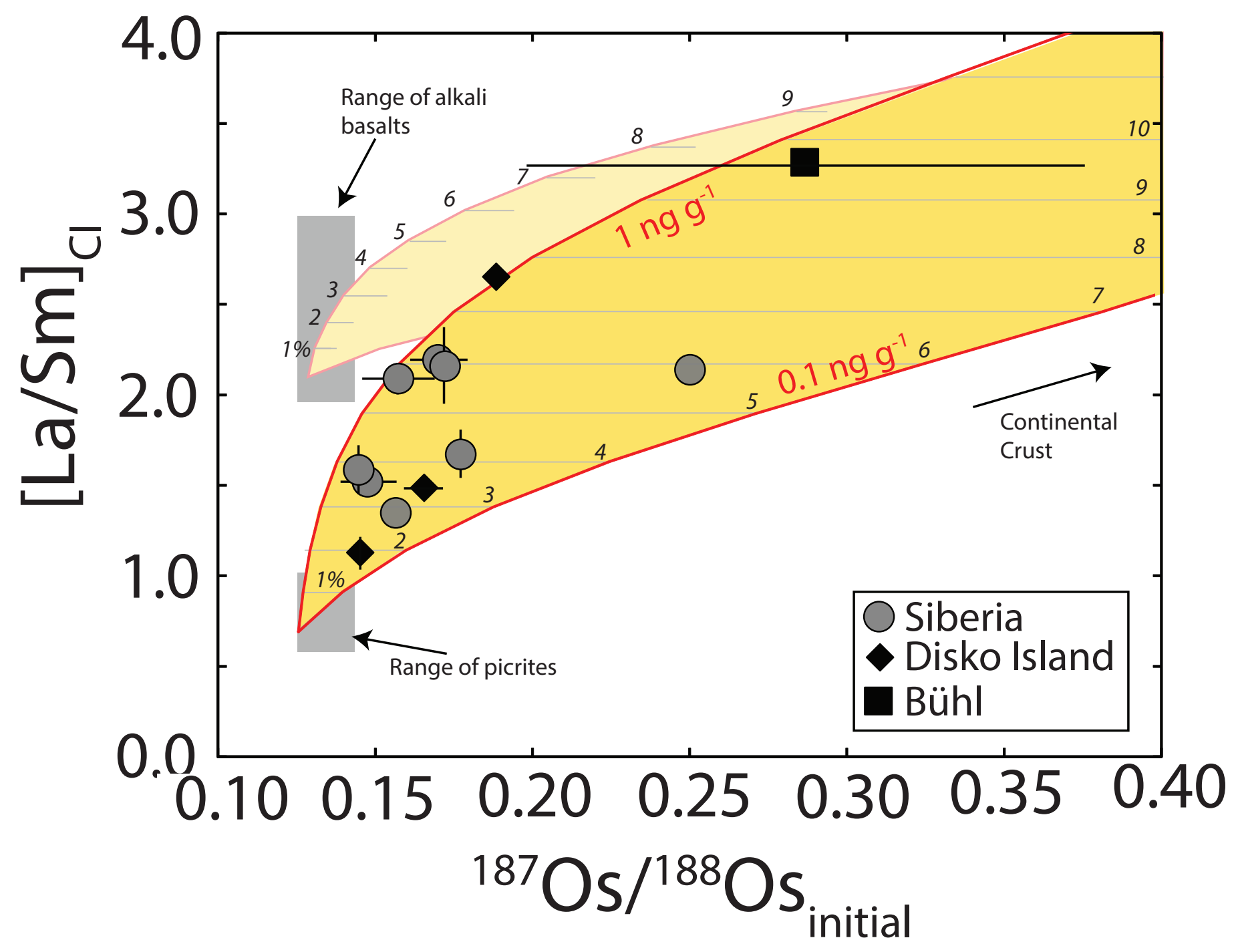

Figure 8 


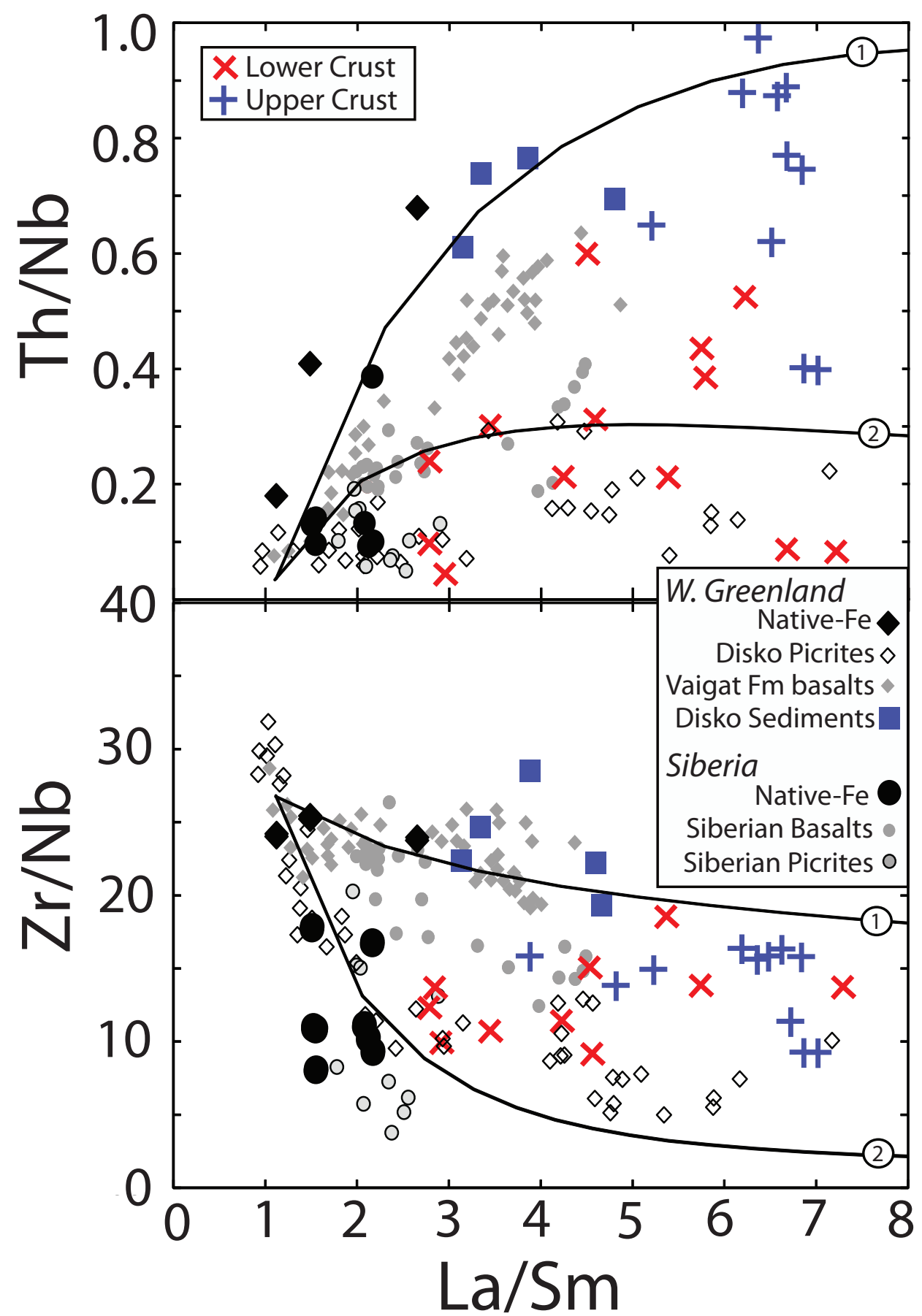

\section{Figure 9}


Table 1: Re-Os isotope and HSE abundance data (in $\mathrm{ng}^{-1}$ ) for native iron basalts and associated sediments

\begin{tabular}{|c|c|c|c|c|c|c|c|c|c|c|c|c|c|c|c|c|}
\hline & Sample & Type & $\begin{array}{c}\text { Mass } \\
(\mathrm{g})\end{array}$ & $\begin{array}{c}\text { Modal \% } \\
\mathrm{Fe}^{0}\end{array}$ & $\operatorname{Re}$ & Pd & Pt & $\mathbf{R u}$ & Ir & Os & ${ }^{187} \operatorname{Re} /{ }^{188} \mathrm{Os}$ & $\pm 2 \sigma$ & ${ }^{187} \mathrm{Os} /{ }^{188} \mathrm{Os}$ & $\pm 2 \sigma$ & $\gamma \mathbf{O s}_{\mathrm{i}}$ & $\gamma \mathbf{O s}_{\mathrm{C}}$ \\
\hline \multirow[t]{13}{*}{ Siberia: } & \multicolumn{16}{|c|}{ Khungtukun ( 250 Ma) } \\
\hline & YHM & Native-Fe cumulate & 0.419 & $>50$ & 123.0 & 6958 & 1552 & 69.7 & 54.1 & 14.6 & 41.64 & 0.96 & 0.33519 & 0.00038 & 28 & 28 \\
\hline & \multicolumn{2}{|c|}{ Repeat } & 0.112 & & 108.3 & 3584 & 2129 & 54.35 & 38.56 & 15.87 & 33.70 & 0.96 & 0.31846 & 0.00026 & 41 & 41 \\
\hline & YIM & Native-Fe cumulate & 0.130 & $\sim 25$ to 50 & 53.90 & 3825 & 1535 & 62.47 & 16.57 & 5.79 & 46.28 & 0.40 & 0.36490 & 0.00069 & 36 & 36 \\
\hline & YLM & Native-Fe cumulate & 0.194 & $<25$ & 0.235 & 6.493 & 10.54 & 1.317 & 0.402 & 0.111 & 10.31 & 0.01 & 0.2089 & 0.0069 & 32 & 31 \\
\hline & \multicolumn{2}{|c|}{ Repeat } & 0.123 & & 0.329 & 6.726 & 6.979 & 1.948 & 0.382 & 0.068 & 23.525 & 0.004 & 0.2459 & 0.0029 & 17 & 17 \\
\hline & \multicolumn{16}{|c|}{ Dzhaltul ( 250 Ma) } \\
\hline & OZ-601 & Native-Fe cumulate & 0.098 & $\sim 25$ to 30 & 79.84 & 5459 & 2169 & 66.43 & 18.60 & 14.96 & 26.18 & 0.85 & 0.26326 & 0.00017 & 22 & 22 \\
\hline & \multicolumn{2}{|l|}{ Repeat } & 0.106 & & 35.25 & 10242 & 6605 & 189.4 & 59.42 & 6.188 & 27.92 & 0.36 & 0.25772 & 0.00024 & 12 & 12 \\
\hline & OZ-82 & Native-Fe cumulate & 0.104 & $\sim 25$ to 30 & 59.92 & 2002 & 1679 & 39.70 & 6.238 & 4.116 & 73.11 & 0.36 & 0.44943 & 0.0007 & 55 & 14 \\
\hline & OZ-101 & Native-Fe cumulate & 0.100 & $\sim 25$ to 30 & 11.56 & 1118 & 143.6 & 6.891 & 0.071 & 1.457 & 39.33 & 0.09 & 0.3410 & 0.0018 & 40 & 40 \\
\hline & OZ-244 & Native-Fe cumulate & 0.108 & $\sim 25$ to 30 & 15.96 & 2186 & 294.6 & 13.00 & 0.205 & 0.845 & 96.17 & 0.09 & 0.55767 & 0.0009 & 24 & 24 \\
\hline & OZ-01-3 & Basaltic Dyke & 0.496 & $\sim 25$ to 30 & 0.515 & 17.63 & 11.07 & 0.574 & 0.097 & 0.102 & 24.97 & 0.01 & 0.3547 & 0.0013 & 99 & 98 \\
\hline \multicolumn{17}{|c|}{ West Greenland: Disko Island ( $\sim 11 \mathrm{Ma})$} \\
\hline & WGLB & Native-Fe cumulate & 0.452 & $>90$ & 160.5 & 196.7 & 817.6 & 107.8 & 108.1 & 125.0 & 6.21 & 0.06 & 0.15180 & 0.00006 & 14 & 15 \\
\hline \multicolumn{3}{|c|}{ Repeat } & 0.087 & & 329.3 & 236.8 & 1234.1 & 134.7 & 151.8 & 190.8 & 8.35 & 0.10 & 0.15486 & 0.00014 & 15 & 16 \\
\hline \multicolumn{3}{|c|}{ Repeat } & 0.106 & & 13570 & 7272 & 84625 & 4525 & 3171 & 11801 & 5.56 & 0.06 & 0.15094 & 0.00002 & 14 & 15 \\
\hline \multirow{2}{*}{\multicolumn{3}{|c|}{$\begin{array}{ll}\mathrm{HC} 80 & \text { Native-Fe basalt } \\
\text { Repeat } & \end{array}$}} & 0.096 & $\sim 15$ to 25 & 53.04 & 54.31 & 98.91 & 19.38 & 8.51 & 10.62 & 24.28 & 0.59 & 0.19502 & 0.00053 & 34 & 34 \\
\hline & & & 0.107 & & 77.61 & 64.66 & 88.99 & 17.97 & 6.97 & 10.17 & 37.15 & 0.64 & 0.20068 & 0.00010 & 29 & 28 \\
\hline & AS80-2B & Native-Fe basalt & 1.003 & $\sim 15$ to 25 & 1.568 & 2.884 & 2.303 & 0.533 & 0.219 & 0.378 & 20.22 & 0.02 & 0.20978 & 0.00037 & 49 & 49 \\
\hline \multicolumn{6}{|c|}{ Germany: Buhl ( 16 Ma) } & 0.01 & 0.00 & & & & & & & & & \\
\hline & BI706 & Native-Fe basalt & 0.434 & $\sim 30$ & 5.980 & 1.147 & 1.043 & 0.202 & 0.118 & 0.155 & 193.35 & 0.03 & 0.4254 & 0.0015 & 193 & 196 \\
\hline \multicolumn{3}{|c|}{ Repeat } & 0.297 & & 5.925 & 0.970 & 2.597 & 0.562 & 0.308 & 0.431 & 67.06 & 0.03 & 0.2160 & 0.0005 & 55 & 57 \\
\hline \multicolumn{17}{|c|}{ West Greenland Sediments: } \\
\hline & DIGX & Graphite Xenolith & 0.196 & & 0.887 & 26.65 & 3.420 & 2.737 & 0.484 & 0.637 & 6.875 & 0.032 & 0.3169 & 0.0036 & 144 & 145 \\
\hline & AS80-4 & Sediment & 0.195 & & 0.146 & 5.242 & 0.956 & 0.741 & 0.119 & 0.065 & 11.851 & 0.003 & 0.8456 & 0.0041 & 556 & 559 \\
\hline & AS80-2 sst & Sediment & 0.995 & & 0.031 & 0.772 & 0.172 & 0.294 & 0.002 & 0.016 & 9.789 & 0.001 & 0.3815 & 0.0030 & 192 & 194 \\
\hline & A80-9 & Sediment & 0.996 & & 0.034 & 1.374 & 1.787 & 0.732 & 0.219 & 0.008 & 24.634 & 0.001 & 1.1568 & 0.0071 & 790 & 794 \\
\hline \multicolumn{3}{|c|}{ Repeat } & 0.108 & & 0.151 & 0.467 & 1.781 & 1.018 & 0.251 & 0.026 & 30.338 & 0.001 & 0.7302 & 0.0079 & 450 & 452 \\
\hline & HC80103 & Sediment & 1.073 & & 0.220 & 0.477 & 0.601 & 0.313 & 0.901 & 0.059 & 19.558 & 0.003 & 0.7464 & 0.0024 & 472 & 474 \\
\hline \multicolumn{3}{|c|}{ Repeat } & 0.101 & & 0.154 & 0.850 & 0.797 & 1.124 & 0.300 & 0.074 & 10.605 & 0.004 & 0.6302 & 0.0021 & 387 & 390 \\
\hline
\end{tabular}

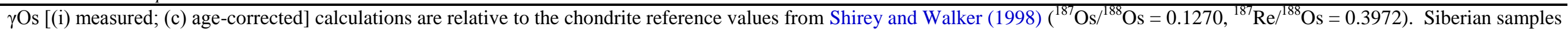

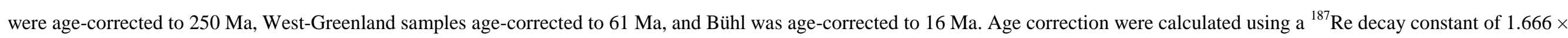
$10^{-11}$ year $^{-1}$ (Selby et al., 2007). 